OECD Statistics Working Papers 2011/07

\title{
Incorporating Estimates of Household Production of Non-Market Services into International Comparisons of Material Well-Being
}

Nadim Ahmad, Seung-Hee Koh 
Organisation de Coopération et de Développement Économiques

Organisation for Economic Co-operation and Development

14-Oct-2011

STATISTICS DIRECTORATE

English - Or. English

INCORPORATING ESTIMATES OF HOUSEHOLD PRODUCTION OF NON-MARKET SERVICES INTO INTERNATIONAL COMPARISONS OF MATERIAL WELL-BEING

\section{STATISTICS DIRECTORATE}

WORKING PAPER No 42

This paper has been prepared by Nadim Ahmad and Seung-Hee Koh, Statistics Directorate

For further information please contact:

Nadim Ahmad - E-mail: Nadim.AHMAD@oecd.org

Seung-Hee Koh - E-mail: Seung-Hee.KOH@oecd.org

JT03309095

Document complet disponible sur OLIS dans son format d'origine

Complete document available on OLIS in its original format 


\section{OECD STATISTICS WORKING PAPER SERIES}

The OECD Statistics Working Paper Series - managed by the OECD Statistics Directorate - is designed to make available in a timely fashion and to a wider readership selected studies prepared by OECD staff or by outside consultants working on OECD projects. The papers included are of a technical, methodological or statistical policy nature and relate to statistical work relevant to the Organisation.

The Working Papers are generally available only in their original language - English or French - with a summary in the other. Comments on the papers are welcome and should be communicated to the authors or to the OECD Statistics Directorate, 2 rue André Pascal, 75775 Paris Cedex 16, France.

The opinions expressed in these papers are the sole responsibility of the authors and do not necessarily reflect those of the OECD or of the governments of its Member countries.

This document and any map included herein are without prejudice to the status of or sovereignty over any territory, to the delimitation of international frontiers and boundaries and to the name of any territory, city or area.

\section{http://www.oecd.org/std/research}

(C) OECD/OCDE, 2011

Applications for permission to reproduce or translate all or part of this material should be made to: OECD Publications, 2 rue André-Pascal, 75775 Paris, Cedex 16, France; E-mail: rights@oecd.org 


\begin{abstract}
This paper reports on work undertaken within the Statistics Directorate to measure the value of household production of non-market services, in order to better compare material well-being across countries. The work is being conducted under the aegis of the National Accounts Working Party and as input into the broader OECD activity on Measuring Progress. It responds to the growing recognition of the need to place a greater emphasis on the development of statistics that focus on the household perspective.

The study shows that at a national level the estimates are acutely sensitive to the value placed on labour used in producing these services. However, it also demonstrates that relatively robust cross-country comparisons are obtainable using estimates converted on a purchasing power parity basis. For China, for example, GDP per capita relative to the United States improves by $50 \%$ when all household production of non-market services is included. Indeed the study demonstrates that including these services is particularly significant for comparisons of 'richer' and ' poorer' countries.
\end{abstract}

Tentative findings extend the idea that volume comparisons over space can be made by looking at volume comparisons over time. However further work will be needed here before more solid conclusions (and results) can be drawn. Indeed the tentative findings point more to the need for a greater evaluation of the comparability of time-use surveys over time and on the quality and related productivity of these nonmarket services.

As part of these future considerations, the Statistics Directorate of the OECD will also investigate the scope for updating these estimates as new time-use surveys become available.

An earlier and shorter version of this paper was published as an Annex in the OECD's 2011 Going for Growth publication (Economic Policy Reforms, 2011, Going for Growth). 


\section{RÉSUMÉ}

Cet article rend compte du travail réalisé au sein de la Direction des Statistiques pour mesurer la valeur des services non marchands produits par les ménages, dans le but d'améliorer la comparaison du bien-être matériel entre pays. Ce travail est accompli sous l'égide du Groupe de Travail sur la Comptabilité Nationale, et censé être incorporé à l'activité plus générale de mesure du progrès de l'OCDE. Il répond à la reconnaissance croissante du besoin de mettre l'accent sur le développement de statistiques centrées sur la perspective des ménages.

Cette étude montre qu'au niveau national, les estimations sont extrêmement sensibles à la valeur attribuée au prix du travail accompli pour la production de ces services. Cependant, il démontre également que des comparaisons relativement robustes entre pays peuvent être obtenues en utilisant des estimations converties sur la base d'une parité de pouvoir d'achat. Pour la Chine par exemple, le PIB par habitant par rapport aux États-Unis est amélioré de 50\% lorsque toute la production de services non marchands des ménages est inclue. L'étude démontre d'ailleurs qu'inclure ces services est particulièrement significatif dans les comparaisons entre pays "riches" et pays "pauvres".

Des résultats préliminaires consolident l'idée que l'on peut effectuer des comparaisons de volume sur l'espace en examinant des comparaisons de volume sur le temps. Ce travail doit toutefois être poursuivi avant de pouvoir tirer de plus solides conclusions. En effet, les résultats préliminaires dénotent le besoin d'une meilleure évaluation de la comparabilité des enquêtes sur l'emploi du temps et de la qualité de ces services non marchands ainsi que la productivité liée à cette qualité.

Dans le cadre de ces considérations futures, la Direction des Statistiques de l'OCDE étudiera aussi la possibilité de mettre à jour ces estimations à mesure que de nouvelles enquêtes sur l'emploi du temps deviennent disponibles.

Une version antérieure et plus courte de cet article a été publiée en tant qu'annexe dans la publication de l'OCDE Objectif Croissance 2011 (Réformes économiques, 2011, Objectif croissance). 
TABLE OF CONTENTS

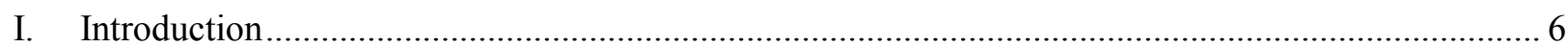

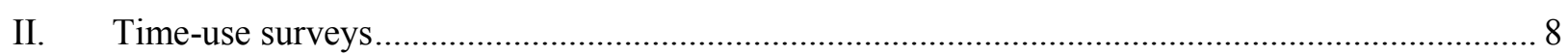

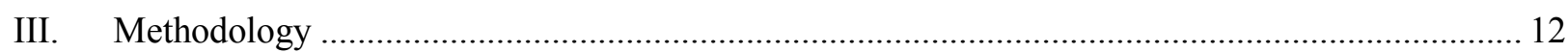

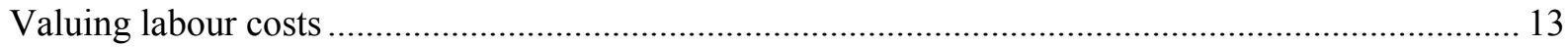

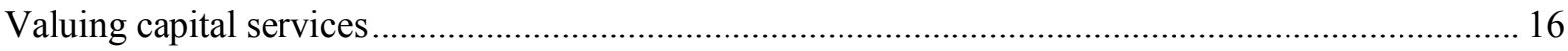

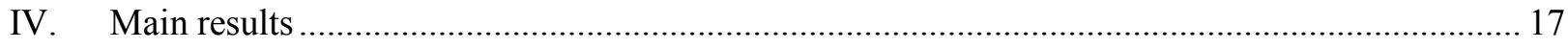

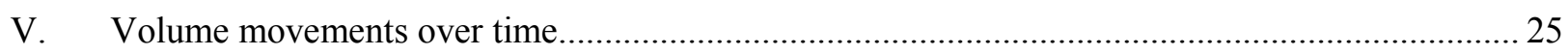

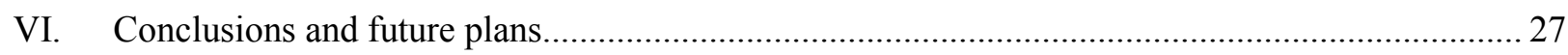

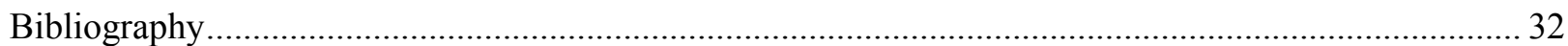




\title{
INCORPORATING ESTIMATES OF HOUSEHOLD PRODUCTION OF NON-MARKET SERVICES INTO INTERNATIONAL COMPARISONS OF MATERIAL WELL-BEING
}

\author{
Nadim Ahmad and Seung-Hee Koh, Statistics Directorate, OECD
}

\section{Introduction}

1. Estimates of production, income and consumption in the System of National Accounts are generally based on the idea that households are final consumers, rather than producers, of goods and services. Goods and services produced by households for the market are included in economic aggregates, as are goods produced for own-consumption, such as agricultural products and own-account construction, but non-market services produced by households for own-consumption, with the notable exception of dwelling services, are not included in economic aggregates in the SNA.

2. There is little contention that many of the services produced by households for their own-use, such as cleaning services, preparation of meals, child-care etc contribute to material well-being and, moreover, that they share the characteristics of the same activities conducted by the market, which are included in the production boundary of the SNA. But they have always been excluded from the SNA production boundary on the general grounds that the transactions could not "be brought directly or indirectly into relation with the measuring-rod of money", (Pigou, 1932) and, in particular, because of the perception that the imputations needed to estimate the size of these activities were relatively arbitrary; therefore reducing the accuracy, credibility, and usefulness of the accounts for analyzing, projecting, and informing policies.

3. Typically, some contention has arisen however in the context of social welfare economics, such as the measurement of material well-being, where the arguments for inclusion in the production boundary are clear, but there has also been concern that the exclusion of such activities from economic aggregates, such as GDP, distorted international comparisons of economic activity; particularly comparisons between developed and developing economies, reflecting the higher proportion of household services, and substitutes such as restaurant services, produced outside of households in developed economies. Indeed, one of the main reasons that imputations for owner-occupied dwelling services are included in GDP is because of the significant distortions that arise in international comparisons when only market rental transactions are recorded in the accounts. In principle, the same argument can be applied when considering the exclusion of other non-market household services.

4. Perhaps the fundamental difference between the two types of services however is the "measuringrod'. With owner-occupied dwellings it is relatively easy to argue that a dwelling, whether owned or rented, provides the same level of service to its household, and, so, the appropriate 'measuring-rod' for owner-occupied dwellings is the equivalent price for market rentals. With other non-market production of services by households however, the appropriate 'measuring-rod' is less clear. For example, what is the appropriate measuring-rod for valuing the labour used in preparing a meal at home by a qualified chef as opposed to the same meal prepared by a qualified accountant? Should it be the price that one would pay for somebody else to prepare the same meal (the replacement cost) or the opportunity cost of the individual making the meal? 
5. The difficulty for the (SNA) accounts is that legitimate arguments can be made in favour of both options, and, moreover, that different types of activities may be considered within and out of scope; leading to widely different estimates of household non-market production, and thus GDP, over time and across countries.

6. A recent study for the United States by Landefeld, Fraumeni and Vojtech (2008), for example, showed that extending the production boundary to include household production of non-market services, not already included in GDP, would increase US GDP by $19 \%$ using the replacement cost approach (using housekeeper's hourly wages), and 62\% using the opportunity cost (using average hourly wages) approach. Interestingly however, average annual real growth over the period, 1985-2004, differed by only $0.1 \%$ percentage point between the two approaches.

7. The broad consensus remains that the core accounts should continue to exclude these activities from the GDP production boundary. However, notwithstanding the inherent measurement difficulties (namely the choice of estimates for labour costs), recent improvements in the statistical infrastructure of many countries (e.g. more detailed data on wages, improved data on non-market activities, and time-use surveys) have led many countries to produce household production satellite accounts (for example Australia, Canada, Finland, Germany, Hungary, Mexico, Nepal, Switzerland the United Kingdom ${ }^{1}$ ) that complement the traditional estimates of economic activity, and that are able to provide a more comprehensive assessment of the material well-being of households. These efforts have recently been given further momentum notably by the recommendations of the Commission on the Measurement of Economic Measurement of Economic Performance and Social Progress (Stiglitz-Sen-Fitoussi).

8. In this context it is important to note that policies designed to improve material well-being based on estimates of household income or consumption that lie within the SNA production boundary (and thus exclude non-market services) may be compromised in two, almost contradictory, ways. For example, estimates of levels of overall actual consumption of goods and services will be underestimated but, at the same time, if more of these non-market services are produced and purchased from the market over-time, estimates of growth in the actual consumption of goods and services will increase. So, on the one hand, levels of material well-being are likely to be underestimated but, on the other, growth is likely to be overestimated. Put more starkly, within the SNA accounting framework, if an individual returned to the work force and paid all of their take-home salary to a domestic servant/nanny to produce the services they were no longer able or willing to, their consumption of goods and services would increase, and, so too, apparently, would their material well-being.

9. It is equally important to note however that the inclusion of non-market household production in estimates of household consumption or income is not a simple panacea in the context of measuring overall, as opposed to material, well-being, as the estimates cannot accommodate for aspects such as 'choice'. Individuals in one country for example may remain at home to raise their children because of a lack of child-care facilities or they may have to return to work through necessity. All other things equal, estimates of household consumption that included non-market services would be the same in both cases but interpretations of comparisons of overall well-being are more complex.

$1 \quad$ Australia: Soupourmas and Ironmonger (2002); Canada: Hamdad (2003) and Harvey and Mukhopadhyay (2005); Finland: Rüger and Varjonen (2008) and Varjonen and Aalto (2006); Germany: Rüger and Varjonen (2008) and Schäfer (2004); Hungary: Szép (2003); Mexico: Gómez Luna (undated); Nepal: United Nations International Research and Training Institute for the Advancement of Women (1996); Switzerland, see http://www.bfs.admin.ch/bfs/portal/fr/index/infothek/erhebungen quellen/blank/blank/ua_sake/01.html; United Kingdom: Francis and Tiwana (2004) and Holloway et al. (2002). Household production accounts exist for two regions in Spain: the Basque region (see Prado and Abando, undated), and Madrid (see Duran, 2007). 
10. Taking advantage of the increasing recognition and demands from policy makers for more comprehensive measures of material well-being, this paper describes recent work undertaken in the OECD Statistics Directorate in response to the developments in the statistical information systems across OECD countries.

\section{Time-use surveys}

11. The results focus on comparisons in 2008 but some tentative results are also presented, towards the end of this paper, for earlier years for some countries. The starting point for the work is the database of time-use surveys collected by the OECD's Employment, Labour and Social Affairs Directorate. This database collates national time use surveys conducted by national statistics institutes using a classification of activities based on 5 main activity categories defined by the OECD. The five main activities are:

i) paid work or study (work-related activities);

ii) unpaid work (household activities);

iii) personal care;

iv) leisure; and

v) other activities not included elsewhere.

12. For the purposes of measuring household production of non-market services, the relevant activity is unpaid work, which can, in theory, be broken down into the following six sub categories: routine housework; shopping; care for household members; care for non household members; volunteer work; and travel related to household activities.

13. The Time-Use surveys available for each country for the main results presented here (for 2008) are based on the most recent year available. For the 27 countries covered in this study the Time-Use surveys relate to time spent in the year as follows: Australia: 2006; Austria: 2008-09; Belgium: 2005; Canada: 2005; China: 2008; Denmark: 2001; Estonia:1999-2000; Finland: 1999-2000; France: 1998-99; Germany: 2001-02; Hungary: 1999-00; Italy: 2002-03; Ireland: 2005; Japan: 2006; Korea: 2009; Mexico: 2009; Netherlands: 2006; New Zealand: 1998-99; Norway: 2000-01; Poland: 2003-04; Portugal: 1999; Slovenia: 2000-01; Spain: 2002-03; Sweden: 2000-01; Turkey: 2006; United Kingdom: 2000-01; and United States: 2008. In countries where there has tended to have been a general trend towards a lower percentage of time spent on unpaid work, estimates for 2008 based on surveys conducted in an earlier period may be biased upwards. However for the periods concerned this is probably not significant.

14. Table 1 below shows the total time spent by households on the five primary activities covered in Time-Use surveys as a per cent of total time. 
Table 1: Breakdown of household activities by category, most recent year ${ }^{(i)}$, per cent

\begin{tabular}{|l|ccccc|}
\hline \multicolumn{1}{|c|}{ Country } & Paid work or study & Unpaid work & Personal care & Leisure & Other \\
\hline Australia & 17 & 17 & 46 & 20 & 1 \\
Austria & 21 & 14 & 45 & 19 & 1 \\
Belgium & 16 & 14 & 48 & 23 & 0 \\
Canada & 22 & 14 & 42 & 21 & 0 \\
China & 24 & 11 & 48 & 16 & 1 \\
Denmark & 16 & 15 & 46 & 23 & 1 \\
Estonia & 20 & 16 & 44 & 20 & 0 \\
Finland & 17 & 14 & 44 & 24 & 1 \\
France & 17 & 14 & 51 & 17 & 0 \\
Germany & 16 & 15 & 45 & 24 & 1 \\
Hungary & 19 & 14 & 47 & 19 & 0 \\
Ireland & 19 & 15 & 43 & 22 & 2 \\
Italy & 18 & 15 & 47 & 20 & 1 \\
Japan & 26 & 11 & 44 & 16 & 2 \\
Korea & 24 & 9 & 45 & 20 & 1 \\
Mexico & 24 & 18 & 43 & 15 & 0 \\
Netherlands & 16 & 15 & 46 & 22 & 1 \\
New Zealand & 19 & 16 & 48 & 17 & 1 \\
Norway & 18 & 13 & 43 & 25 & 0 \\
Poland & 17 & 16 & 45 & 21 & 1 \\
Portugal & 20 & 15 & 47 & 17 & 0 \\
Slovenia & 18 & 16 & 44 & 22 & 0 \\
Spain & 19 & 14 & 46 & 21 & 0 \\
Sweden & 20 & 15 & 43 & 22 & 1 \\
Turkey & 17 & 17 & 46 & 18 & 1 \\
United Kingdom & 18 & 15 & 44 & 22 & 1 \\
United States & 20 & 14 & 44 & 20 & 1 \\
\hline (i) See paragraph 13 for more details & & & & & \\
Soura & 11 & & &
\end{tabular}

Source: OECD estimates based on national time-use surveys (2011)

15. Table 1 shows that there are large variations across countries for some of the categories. Average per cent of time spent on paid work or study for example ranges from 16 per cent in Belgium and the Netherlands to 26 per cent in Japan. And the average per cent of time spent on un-paid work ranges from 9 per cent in Korea to 18 per cent in Mexico. However to some extent, perhaps not surprisingly, the overall per cent of time spent on the two categories combined is relatively similar (see Figure 1 below), which gives weight to the argument that there is some degree of substitutability between the two categories; affected by a number of factors including lifestyle choice and indeed the relative remuneration of paidwork versus the implicit remuneration in unpaid work. 
Figure 1: Per cent of total time spent on unpaid-work and paid-work/study ${ }^{(i)}$

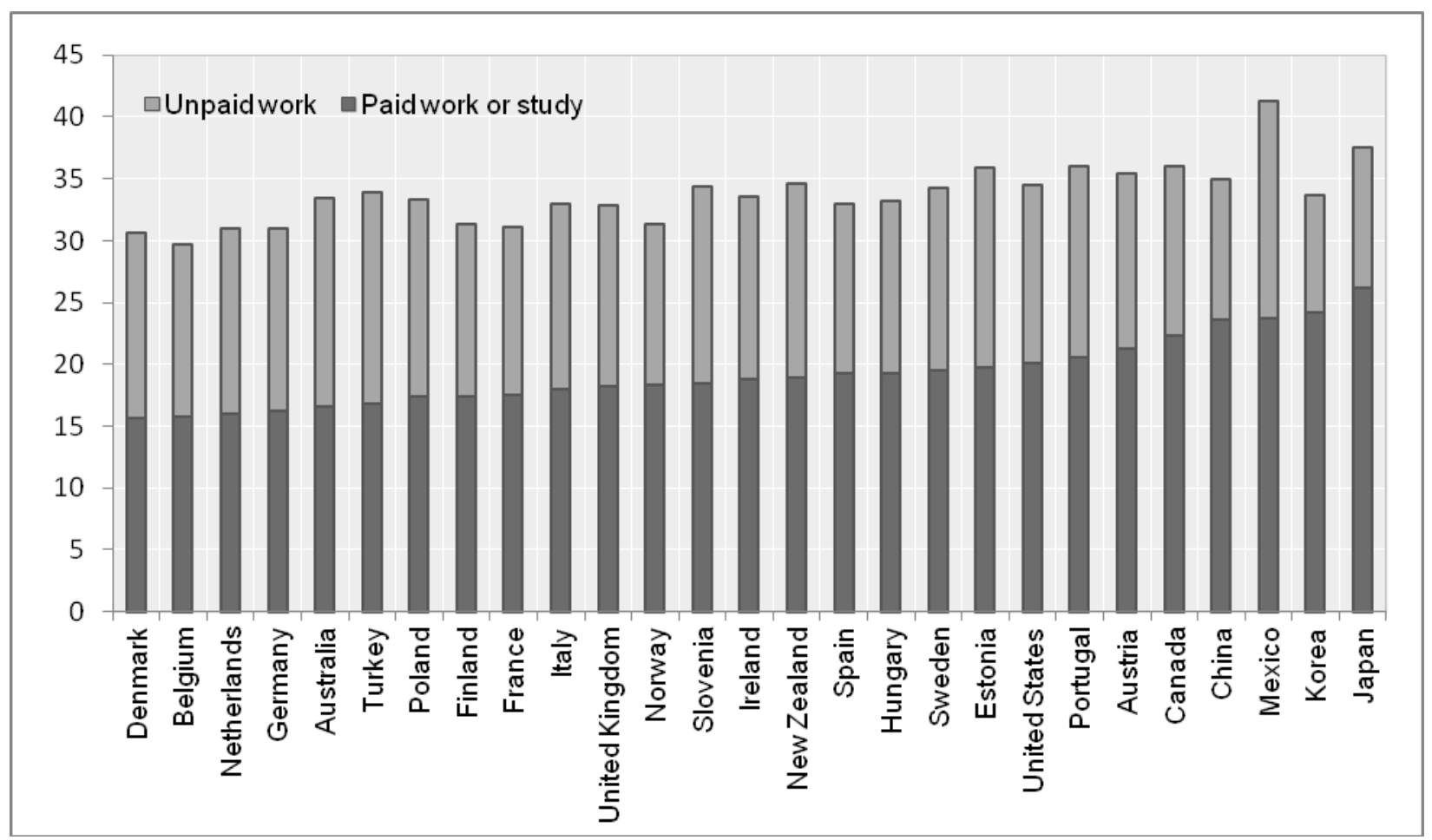

(i) See paragraph 13 for more details

Source: OECD estimates based on national time-use surveys (2011)

16. Clearly, there may be some quality issues concerning the time-use surveys as is the case with any statistics that typically survey households but the fact that the total average per cent of time spent on both un-paid work and paid work/study is relatively similar is a reassuring sign, particularly in the context of the very low figures of $9 \%$ and $11 \%$ spent on un-paid work in Korea and Japan respectively. That is not to say that there should necessarily be a very similar proportion of time spent on these two activities across all countries as a number of factors could justify differences, for example there may be greater use of timesaving durables in those countries with low proportions of time spent on un-paid work/study.

17. Table 2 shows the percentage of total time spent on household production of non-market services broken down by category (with care for household and non-household members aggregated). 
Table 2: Breakdown of time spent on household non-market production by category ${ }^{(i)}$, per cent

\begin{tabular}{|c|c|c|c|c|c|}
\hline Country & $\begin{array}{l}\text { Routine } \\
\text { housework }\end{array}$ & Shopping & $\begin{array}{l}\text { Care for household } \\
\text { members \& non- } \\
\text { household members }\end{array}$ & Volunteering & $\begin{array}{c}\text { Travel related to } \\
\text { household activities }\end{array}$ \\
\hline Australia & 54 & 12 & 18 & 2 & 13 \\
\hline Austria & 62 & 10 & 18 & 2 & 8 \\
\hline Belgium & 67 & 13 & 8 & 3 & 10 \\
\hline Canada & 55 & 15 & 18 & 1 & 11 \\
\hline China & 63 & 12 & 15 & 1 & 9 \\
\hline Denmark & 59 & 12 & 18 & 1 & 10 \\
\hline Estonia & 65 & 10 & 16 & 0 & 8 \\
\hline Finland & 60 & 14 & 16 & 2 & 8 \\
\hline France & 68 & 16 & 14 & 1 & 2 \\
\hline Germany & 58 & 15 & 13 & 3 & 11 \\
\hline Hungary & 64 & 11 & 10 & 0 & 15 \\
\hline Ireland & 43 & 13 & 29 & 4 & 11 \\
\hline Italy & 64 & 13 & 13 & 1 & 9 \\
\hline Japan & 61 & 16 & 11 & 2 & 9 \\
\hline Korea & 58 & 10 & 22 & 1 & 10 \\
\hline Mexico & 73 & 7 & 17 & 0 & 3 \\
\hline Netherlands & 54 & 12 & 16 & 2 & 15 \\
\hline New Zealand & 53 & 10 & 21 & 6 & 10 \\
\hline Norway & 61 & 12 & 17 & 1 & 9 \\
\hline Poland & 63 & 10 & 18 & 0 & 9 \\
\hline Portugal & 72 & 7 & 11 & 1 & 9 \\
\hline Slovenia & 72 & 8 & 12 & 0 & 8 \\
\hline Spain & 64 & 13 & 15 & 1 & 8 \\
\hline Sweden & 60 & 12 & 15 & 2 & 11 \\
\hline Turkey & 57 & 6 & 13 & 8 & 16 \\
\hline United Kingdom & 58 & 14 & 15 & 1 & 12 \\
\hline United States & 49 & 13 & 20 & 4 & 13 \\
\hline
\end{tabular}

(i) See the paragraph 13 for more details

Source: OECD estimates based on national time-use surveys (2011)

18. Ideally, the approach to value household non-market production of services would estimate each of the components separately, using prices specific to the type of service. However, the information to do this is limited and, as such, it is assumed that the implicit price or value of the labour used in providing the services is the same for all categories (further details are provided below).

19. The important point to make here is the possibility of double-counting. Some of the time spent on household production of non-market services will be spent on activities related to the production of goods such as agricultural products for own-use, or the production of goods such as community housing, through voluntary work, that are not for own-use. The output related to the production of these goods will, at least in theory, be included within estimates of GDP, so, estimates of household production of non-market services that do not correct for these activities will be biased upwards.

20. It is equally important to note that not all voluntary work will be consumed by households. For example voluntary work can include assisting teachers in schools, providing support to youth clubs and sporting activities, working in charity shops, working as guides in museums and galleries etc, and so estimates of household consumption that include these activities will also be biased upwards when the 
output of these activities is directly estimated rather than based on a sum of costs approach. However, as shown in Table 2, the amount of time spent on volunteering services is generally around $2 \%,(8 \%$ in Turkey), and, so, no explicit adjustments are made in the results that follow for this potential double counting. In any case, as noted above, not all of the time spent on volunteering services is necessarily included in GDP estimates, and no information is readily available to allow a robust split of the time spent on volunteering into a part that is already included in official GDP estimates and a part that is not. At the same time, also because of a lack of information, no adjustments are made for the potential double counting of time spent producing goods for own consumption. In this context it is important to note that some of the time spent producing these goods may be included under responses to time spent on leisure, for example gardening, fishing, depending on the respondent's perspective.

\section{Valuing leisure}

From a time-use perspective, value could be given to other ways in which time is spent; in particular leisure, on which, on average individuals spend about $20 \%$ of their time compared to $15 \%$ on unpaid work and about $20 \%$ on paid work. Placing a value on time spent on leisure, such that it can be compared with the benefits gained from conventional consumption of market goods and services or the consumption of goods and services produced by households for their own-use, is considerably more challenging, both empirically and conceptually, than finding values for time spent on household production of goods and services; where market price equivalents of the goods and services produced are increasingly available. Moreover it's important to note that the concept of time spent on leisure does not always satisfy the underlying SNA basic first criterion (M. Reid (1934), T. P. Hill (1979)) for inclusion in the production boundary - namely that the associated good or service has to be capable of being provided by someone else. In this sense, however vital sleeping, exercising and socialising are for individuals' well-being these are not productive acts in the economic sense, and, so, no attempt at estimating the value of leisure services are included here.

\section{Methodology}

21. In principle, two approaches exist to measure the total value of household production of nonmarket services. The first approach takes market price equivalents of the non-market services and applies these, adjusted for differences in quality, to the quantity of non-market services produced by households ${ }^{2}$. But this approach is non-trivial as it requires good quality market price equivalent measures and data on quantities of services provided; neither of which is readily available. The second, more usual, and achievable, approach is to measure the sum of costs involved in producing the non-market services. These costs include the intermediate consumption involved in producing the services, the costs of labour and the value of capital services used in production.

22. In practice however, as is the case in this paper, references and estimates of the value of household non-market production of services typically only measure the value-added component of these activities (i.e. the labour and capital services components). This is partly because the goods and services used as intermediate consumption in the production of non-market services (such as food products used to produce meals) are already included in estimates of household final consumption. But also because estimates of how much of the share of household final consumption that is used in producing non-market services (and, so, the intermediate consumption component) is not readily available.

23. As such, all references below to the value of household production of non-market services should be interpreted as the value-added component of these services (excluding of course the value of ownerSee for example, Holloway S, S Short and S Tamplin, Household Satellite Account (Experimental) Methodology
London: ONS 2002 
occupied dwellings services which are already included in estimates of household final consumption in the SNA).

\section{Valuing labour costs}

24. Two approaches are used to estimate the value of the labour supplied in producing these services. The first is the replacement cost approach, where an average post-tax, hourly wage, representative of the broad range of activities covered in the production of household production of non-market services, is constructed using data collected in the Eurostat-OECD Purchasing Power Parities (PPP) programme. The second approach, which aims at providing some measure of the potential range of estimates (in practice an upper bound of sorts), is the opportunity $\operatorname{cost}^{3}$ approach, which takes the average post-tax hourly wage across the whole economy. Table 3 below provides a summary of the sources used for each country.

25. Conceptual arguments can be made in favour of both the opportunity and replacement cost approach. In practice, most studies have produced estimates based on replacement costs following the underlying valuation principle that the ultimate goal is to obtain an equivalent market value of the nonmarket services produced; in other words, the price that would be paid for somebody else to produce the same quantity and quality of service.

26. One could argue that the cost of labour for any individual would approach the opportunity cost to the individual concerned i.e. how much could he/she earn if he/she spent his/her time in his/her paid employment rather than in producing non-market services. Certainly this would be true if the non-market activity was the same as the individual's paid profession. But the arguments in favour of the replacement cost approach, namely the equivalent price of labour in producing the same services (and quality of service), are considered more in line with national accounts concepts. Moreover, the opportunity cost approach necessarily assumes that a person outside the labour market - e.g. a full-time housewife or retiree - would be able to find a job on the market according to his or her qualifications, which is a stretching assumption. One could just as convincingly argue that the opportunity cost was zero (see also, Abraham and Mackie (2007)), for example, in the extreme case that the individual's competencies have no value on the labour market.

27. This suggests that, ideally, the underlying general principle for the valuation of hourly labour costs should be the quality-adjusted price of a specialist worker in the activity being measured, where the quality is adjusted to reflect the productivity of non-specialised individuals. In practice however, as is the case in this study, many studies do not adjust for quality, and those that do generally do so using relatively arbitrary estimates that assume that the quality/productivity of the non-specialist is likely to be lower. Landefeld et al. (2008), for example, assumed that the average hourly wage, used as a proxy for the replacement cost, was $75 \%$ of the specialist hourly wage in a number of activities.

28. Because no information is available on the prices of specialised labour in specific activities this paper uses a general hourly labour cost based on prices of market activities that are representative of the main activities conducted by households in the production of non-market services, such as the costs for unregistered domestic servants. Ideally, specific price indices for each specific activity would be used. But because routine housework forms the major activity in all countries, the results are not expected to be significantly adversely affected by using the price for routine housework for all activities.

29. The estimates of hourly wages for both the replacement and opportunity cost approach used here are net-of taxes and social security contributions. Not all studies have estimated labour costs on this basis. Some, for example, use gross measures. This study creates an equivalence (of sorts) between the concepts

3 A full opportunity cost approach would calculate the opportunity costs for each individual. 
used to estimate the labour costs of unregistered (informal) labour and unpaid labour provided by households in non-market production. The reference to an 'equivalence of sorts' reflects the fact that this is not a perfect equivalence. In practice the payments made to informal workers may often include a component of the tax that consumers would have paid if the activity was provided formally, reflecting a sharing of the 'tax-free' dividend between the consumer and the producer. The decision to use hourly wages net of taxes and social security contributions partly reflects practicalities - namely, in the absence of any further information, the difficulty in splitting the 'dividend' - but also a desire to have a de facto (prudent) lower bound that can be used in juxtaposition to the 'upper' bound provided by the opportunity cost approach.

30. For the replacement cost approach, when direct estimates of the hourly wages of unregistered workers are not available, estimates of hourly post-tax wage costs are based on hourly wage costs of registered workers adjusted for taxes and social security contributions using data from OECD Taxing Wages 2009, where the tax 'wedge' reflects the average of:

(i) the tax and social security contributions paid by employees, as a percent of total wages, for a single person with no children earning two-thirds of the national average annual salary; and

(ii) the tax and social security contributions paid by employees, as a percent of total wages of a single person with two children earning two-thirds of the national average annual salary.

31. The choice of the two categories above in the calculation of the tax wedge for the replacement cost approach is based on the observation that in those countries where prices for unregistered workers are available they are typically at the lower end of the salary scale. 
Table 3: Sources and methods to estimate post-tax hourly wages

\begin{tabular}{|c|c|c|}
\hline Country & Replacement cost approach & Opportunity cost approach \\
\hline Australia & $(2)$ & $(4)$ \\
\hline Austria & (1) & (3) \\
\hline Belgium & (1) & (3) \\
\hline Canada & (1) & (4) \\
\hline China & $\begin{array}{l}\text { Based on the replacement cost in the United States } \\
\text { adjusted using the PPP derived for average salaries } \\
\text { in the United States and China }\end{array}$ & $\begin{array}{l}\text { Annual gross average salary } 2008 \text { for urban } \\
\text { residents (source: National Bureau of } \\
\text { Statistics of China) }\end{array}$ \\
\hline Germany & (1) & (3) \\
\hline Denmark & (1) & (3) \\
\hline Spain & (1) & (3) \\
\hline Finland & (1) & (3) \\
\hline France & (1) & (3) \\
\hline $\begin{array}{l}\text { United } \\
\text { Kingdom }\end{array}$ & (1) & $(4)$ \\
\hline Hungary & (1) & (3) \\
\hline Ireland & (1) & $(4)$ \\
\hline Italy & (1) & (3) \\
\hline Japan & $(2)$ & $(4)$ \\
\hline Korea & $(1)$ & $(4)$ \\
\hline Mexico & $50 \%$ of the average net wage for the total economy & $(4)$ \\
\hline Netherlands & $(1)$ & $(3)$ \\
\hline Norway & $\begin{array}{l}\text { Average of an hourly wage of a child care worker } \\
\text { (source, based on Statistics Norway statistics) and } \\
\text { OECD PPP survey data, adjusted for tax and social } \\
\text { security contributions. }\end{array}$ & $(4)$ \\
\hline New Zealand & $(1)$ & $(3)$ \\
\hline Poland & $50 \%$ of the average net wage for the total economy & $(3)$ \\
\hline Portugal & (1) & $(4)$ \\
\hline Sweden & (1) & (3) \\
\hline Turkey & $50 \%$ of the average net wage for the total economy & $(4)$ \\
\hline United States & $(1)$ & $(3)$ \\
\hline Estonia & $50 \%$ of the average net wage for the total economy & (3) \\
\hline Slovenia & (1) & $\begin{array}{l}\text { Average of monthly net wages } 2008 \text { (source: } \\
\text { Statistical Office of the Republic of Slovenia) }\end{array}$ \\
\hline (1) & \multicolumn{2}{|c|}{ Based on OECD PPP survey data for wage costs in relevant unregistered activities. } \\
\hline$(2)$ & \multicolumn{2}{|c|}{$\begin{array}{l}\text { Based on OECD PPP survey data for wages costs in relevant registered activities with adjustments } \\
\text { for tax and social security contributions based on estimates from OECD "Taxing Wages 2009" }\end{array}$} \\
\hline (3) & \multicolumn{2}{|c|}{$\begin{array}{l}\text { Average hourly gross wages: based on OECD Structural Analysis (STAN) and Productivity } \\
\text { databases. Tax and social security contributions estimated from OECD "Taxing Wages 2009". }\end{array}$} \\
\hline$(4)$ & \multicolumn{2}{|c|}{$\begin{array}{l}\text { Average hourly gross wages: based on annual earnings estimates in "Taxing Wages } 2009 \text { " and hours } \\
\text { worked data in the OECD Productivity database. Tax and social security contributions estimated from } \\
\text { OECD "Taxing Wages 2009". }\end{array}$} \\
\hline
\end{tabular}


32. Similarly, for the opportunity cost approach the average tax wedge is calculated as the average of:

i) the tax and social security contributions as a percent of total wages paid by a single person earning $100 \%$ of the national annual average salary; and

ii) the tax and social security contributions as a percent of total wages paid by a sole earner married with two children earning $100 \%$ of the national annual average salary.

33. It is important to note in this context that estimates of 'net' (post-tax) prices based on registered workers may be biased downwards in comparison to the actual labour costs of unregistered workers since the price of labour charged by unregistered workers may appropriate some part of the implicit tax-wedge. However, notwithstanding this possibility, it is all the same useful to focus on post-tax estimates of the value of labour because they provide the basis for a more meaningful lower-bound of overall household production of non-market services that can be used in parallel with the de-facto upper bound created by opportunity costs; thus creating upper and lower bound estimates that can be used with a relatively high degree of statistical confidence.

34. The overall approach to measure the (replacement of opportunity) costs of labour used in the production of household non-market services for own use can therefore be simply described as follows:

Value of annual labour used in household production of non-market services in nominal currencies

$$
\begin{gathered}
= \\
\text { average hourly post-tax labour costs } \\
* \\
\text { average hours worked per day } \\
* \\
365 \text { (in 2008) } \\
*
\end{gathered}
$$

population 15 years and above.

\section{Valuing capital services}

35. Like any other activity, capital and labour can to some extent be used interchangeably in the production of household non-market services. Clearly innovations and inventions such as the dishwasher, washing machine, microwave, etc. have provided possibilities for substitution with labour. Including the contribution of such consumer durables is important therefore to fully reflect the consumption of goods and services by households in a consistent way across countries and over time.

36. Consumer durables used in this analysis are based on the Eurostat-OECD Classification of Final Expenditure on GDP categories ${ }^{4}$, which includes household appliances, motor vehicles and also categories of consumer durables, such as furniture, that provide capital services related to dwelling services. It is important to note that the estimates of capital services produced below will be biased upwards since some consumer durables, such as cars, also provide capital services to commuting and leisure activities; and not just household non-market services. Future work will attempt to allocate only the relevant part of consumer durables to estimates of capital services used in household production of non-market services.

4 The precise classification categories used are: 11.05.11.1, 11.05.12.1, 11.05.31.1, 11.05.51.1, 11.06.13.1, 11.07.11.1, 11.07.11.3-5, 11.07.12.1, 11.07.13.1, 11.07.14.1, 11.08.21.1, 11.09.11.1, 11.09.12.1, 11.09.13.1, 11.09.21.1, 11.09.22.1, 11.12.31.1 
37. The approach is to create estimates of the value of capital services (by estimating the productive stock of consumer durables constructed using the perpetual inventory method) based on the standard stockflow relationship:

$$
\mathrm{K}^{\mathrm{t}}=\mathrm{K}^{\mathrm{t}-1}(1-\delta)+\mathrm{I}^{\mathrm{t}}
$$

Where, $\mathrm{K}^{\mathrm{t}}$ is the end-of the period net stock of consumer durables, $\mathrm{I}^{\mathrm{t}}$ is the flow of purchases of consumer durables during period $t$ in constant (chained) prices, $\delta$ is the geometric rate of depreciation, set at $20 \%{ }^{5}$. Note that no distinction is made between different types of consumer durables in this analysis but this will be the subject of further work, as, indeed, will be assumptions concerning the depreciation rate.

38. The value of capital services (Jorgenson and Griliches, 1967) is measured as the price of capital services per unit of the net stock multiplied by the net stock. The capital service price contains three elements: a return to capital, depreciation, and revaluation of capital goods. We estimate a simplified version of the capital service price for consumer durables as:

$$
\mathrm{P}_{\mathrm{K}}{ }^{\mathrm{t}}=\mathrm{P}_{\mathrm{I}}^{\mathrm{t}}[\mathrm{r}+\delta]
$$

Where $\mathrm{r}$ is the real rate of return, set at $4 \%{ }^{6}$ per year, $\mathrm{P}_{\mathrm{K}}{ }^{\mathrm{t}}$ is the price of capital services and $\mathrm{P}_{\mathrm{I}}{ }^{\mathrm{t}}$ is the price index of consumer durables. The value of capital services from consumer durables is therefore (again, future work will investigate the impact of different rates of return on the overall results):

$$
\mathrm{P}_{\mathrm{K}}{ }^{\mathrm{t}} \mathrm{K}^{\mathrm{t}}=[\mathrm{r}+\delta] \mathrm{P}_{\mathrm{I}}^{\mathrm{t}} \mathrm{K}^{\mathrm{t}}
$$

\section{Main results}

39. Figure $2^{7}$ below summarises the information available from the time-use surveys for 26 OECD countries and China. It shows that in most OECD countries the average time spent on unpaid household work falls between 3 and 4 hours per day, with the notable exception of Korea, where the average is just over two hours per day.

5 The choice of $20 \%$ for the depreciation rate has been partly informed by observed depreciation rates in similar capital goods, such as vehicles and computers.

6 The choice of $4 \%$ is based largely on convention and practice used in similar studies.

7 Note that the age cohorts covered by time-surveys typically cover 15-64 only (except Australia: $15+$, China: 1574. Hungary: 15-74. and Sweden: 20-64); however, the results shown here are for the entire population of 15 and above. This assumes that the time spent on production of household services by the $65+$ age cohort is the same, per head, as the 15-64 cohort. 
Figure 2: Average hours spent on unpaid household work per person per day in recent years ${ }^{(i)}$

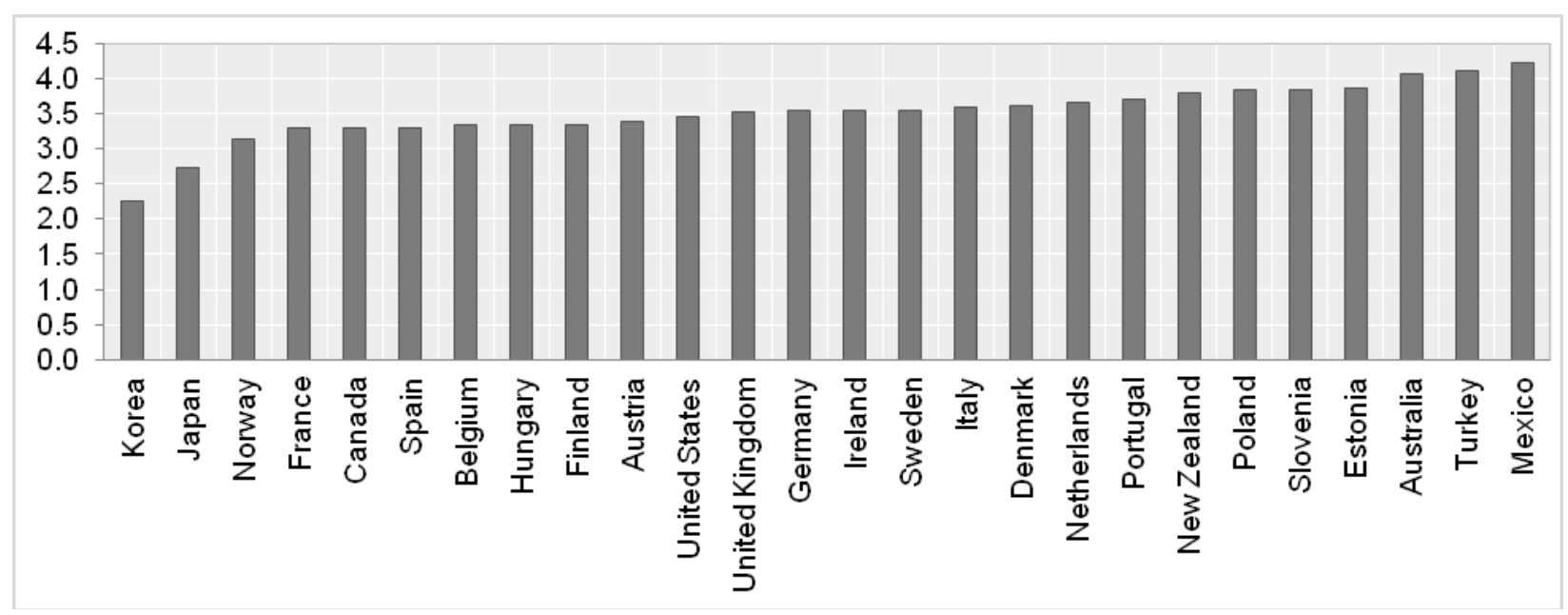

(i) See paragraph 13 for more details.

Source: OECD estimates based on national time-use surveys (2011)

40. Figure 3 below presents the value of labour costs in household production of non-market services as a percentage of GDP based on the replacement cost approach and the opportunity cost approach.

41. Not surprisingly (given the significant differences in the values of labour between the replacement and opportunity cost approaches), the chart shows considerable variations in the contribution of labour to household production of non-market services, depending on the approach. The contribution is close to $70 \%$ of GDP for example in the United Kingdom using the opportunity cost approach but about $25 \%$ using the replacement cost approach.

42. This, to some extent, confirms the concerns of many national accountants that the inclusion of these estimates within the GDP production boundary could risk undermining rather than strengthening it. Interestingly, as shown in Figure 4 there is no strong negative correlation with household adjusted individual consumption (AIC) per capita, as one might have intuitively thought a priori.

43. For example, household non-market production in Mexico as a per cent of total AIC is roughly half that of the equivalent per cent in New Zealand, which has roughly twice as much AIC per capita on a PPP basis than Mexico. 
Figure 3: Value of labour costs in household production of non-market services, \% of GDP, 2008

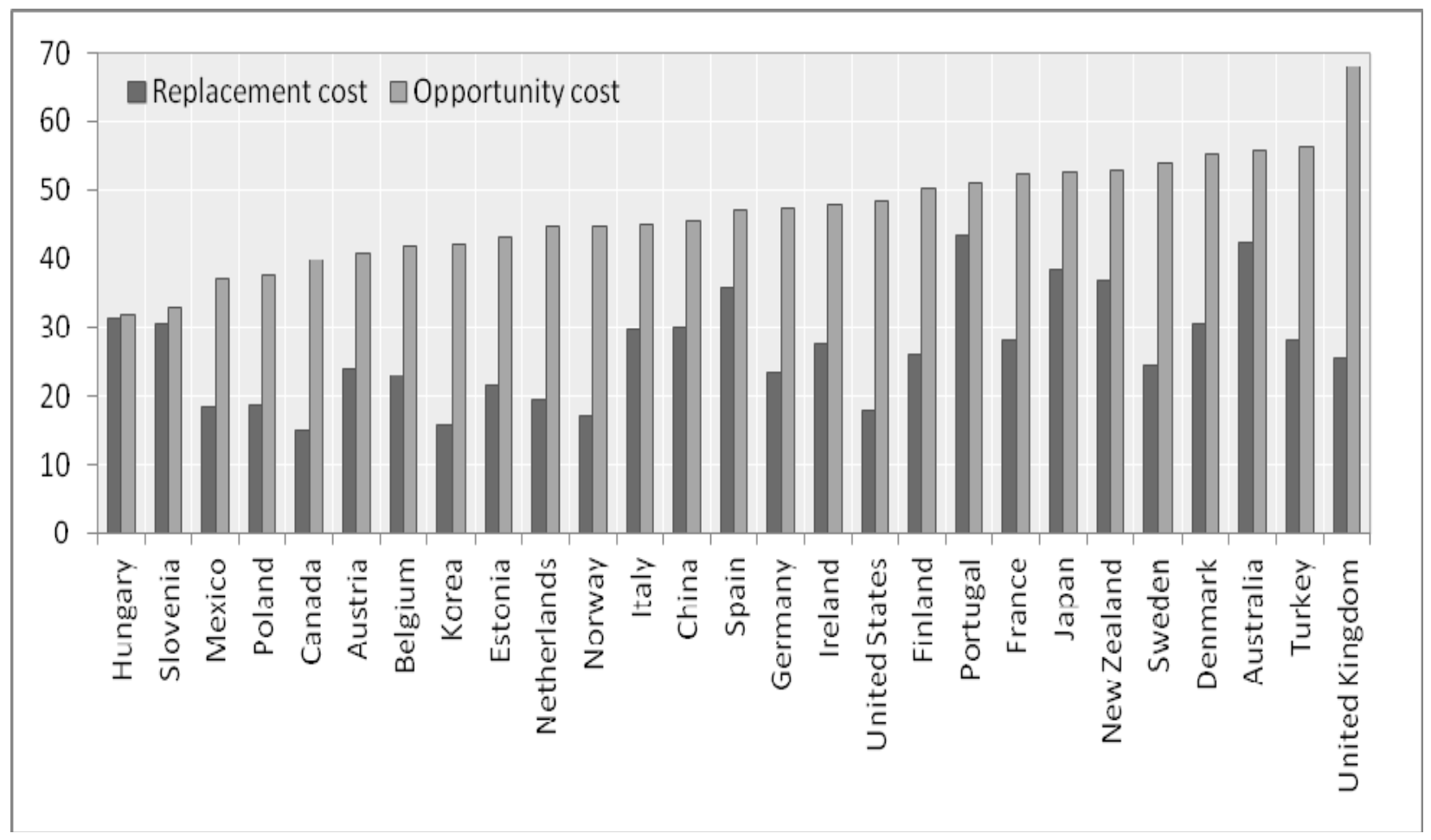

Figure 4: Household production of non-market services (replacement cost approach), as a per cent of AIC (national currency) and AIC per capita USD, 2008, PPP

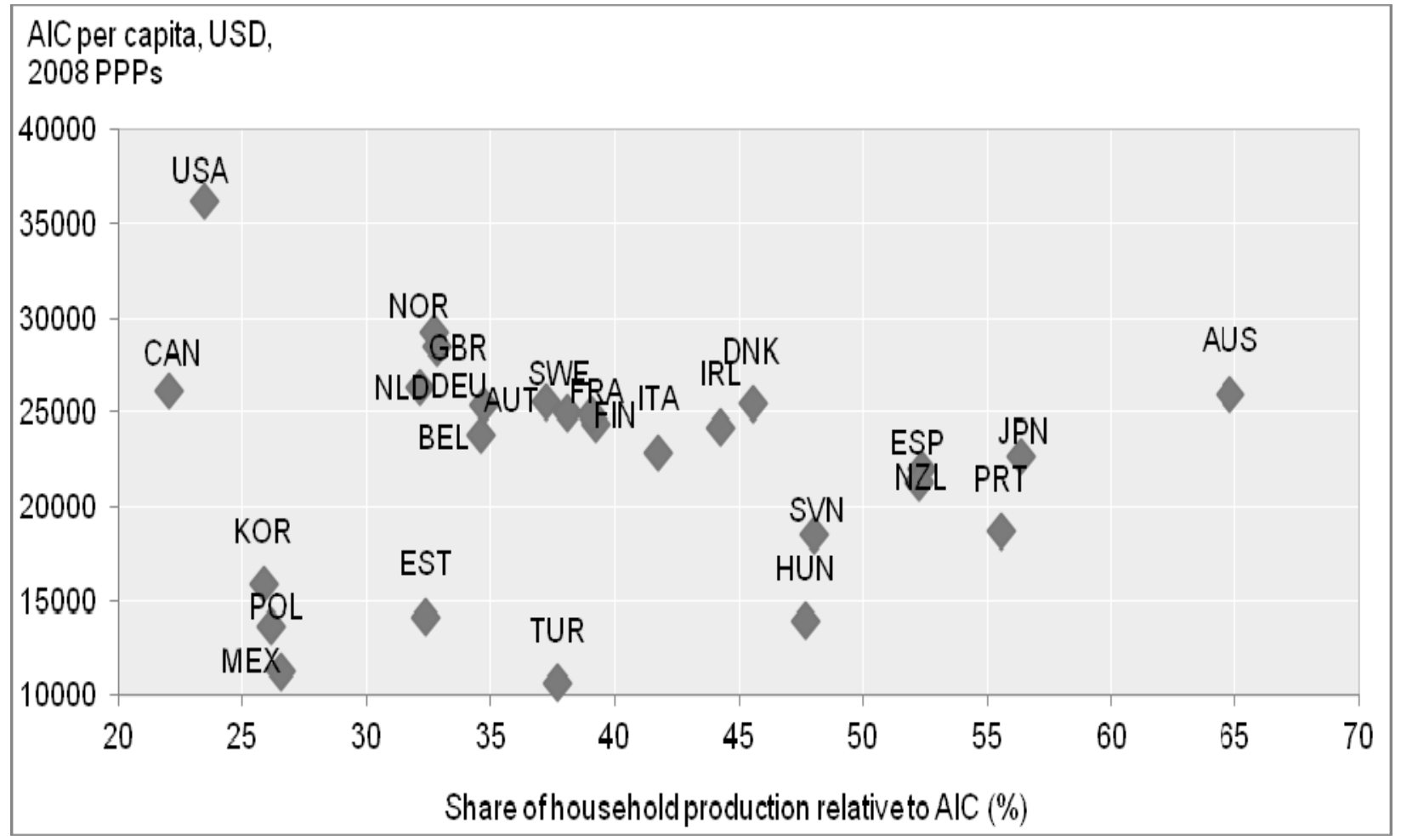


44. This point reinforces the care needed in selecting the price of labour. However, although the range of estimates is acutely sensitive to the choice of the price of labour, volume comparisons (as shown below), that compare countries using purchasing power parities (PPP), are much less affected by the choice of price, and in particular to whether a replacement cost or opportunity cost approach is used. Indeed Landefeld et al. (2008) also demonstrated that this was the case (for the United States) for volume comparisons over time. Some tentative results are also presented towards the end of this paper looking at volume movements over time in five OECD countries and where further work is needed.

45. Figure 5, below, illustrates the fact that the selection of either a replacement cost or opportunity cost approach does not significantly change PPP comparisons by comparing replacement cost and opportunity cost estimates of total household consumption per capita in 2008 PPPs with the United States set at 100; where total household consumption refers to adjusted individual consumption (AIC) $)^{8}$ plus the imputed labour costs for household production of non-market services and is used rather than GDP per capita as the concept of actual individual consumption aligns more closely to material well-being. Figure 6 shows similar results using GDP as the reference.

46. Perhaps the single most striking finding is that the relative rankings of countries is little changed whether the opportunity cost or replacement cost approach is used, and that the positions relative to the United States are generally similar for both approaches - with the opportunity cost approach typically coming in no more than 5 points higher than the replacement cost approach on average. The most important message from a policy, as opposed to statistical, perspective however, is the fact that the positions of countries at the lower end of the consumption scale, relative to the US, (e.g. Mexico and Turkey), improve significantly when estimates of household production of non-market production are accounted for. Indeed, comparisons of total household consumption show improvements in the position of all countries relative to the United States. In addition the positions of Turkey, Mexico, Poland, Hungary, and Estonia, improve markedly compared to the position of Korea, reflecting in large part the relatively low per cent of time spent on un-paid work in Korea.

47. The same general results hold when comparisons of GDP per capita are made, although in this case the position of Norway falls relative to the United States. For China the position relative to the United States is markedly different. Its GDP per capita increases by nearly $50 \%$ when measured on a replacement cost basis and by over $80 \%$ on an opportunity cost basis.

8 When references to adjusted individual consumption are made in the context of estimates of total household consumption, AIC is exactly equivalent to household actual final consumption as described in the 2008 SNA (\#9.81). When references to AIC are made in the context of total household consumption including the contribution of capital services however, AIC reflects household actual final consumption minus final expenditures on consumer durables. 
Figure 5: Total household consumption of non-market services: 2008 PPPs, US=100

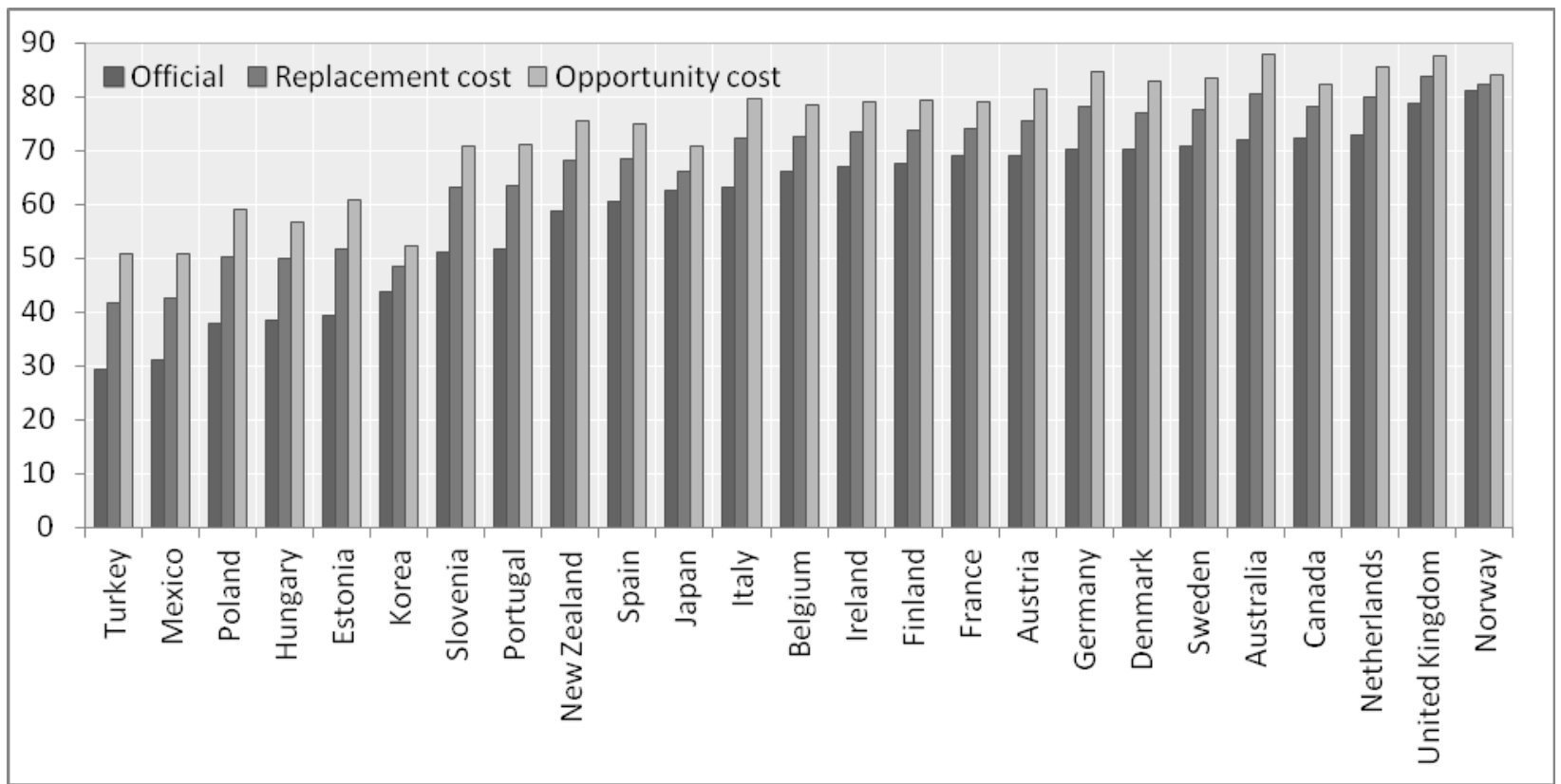

Figure 6: GDP per capita with and without household consumption of non-market services: 2008 PPPs, US $=100$

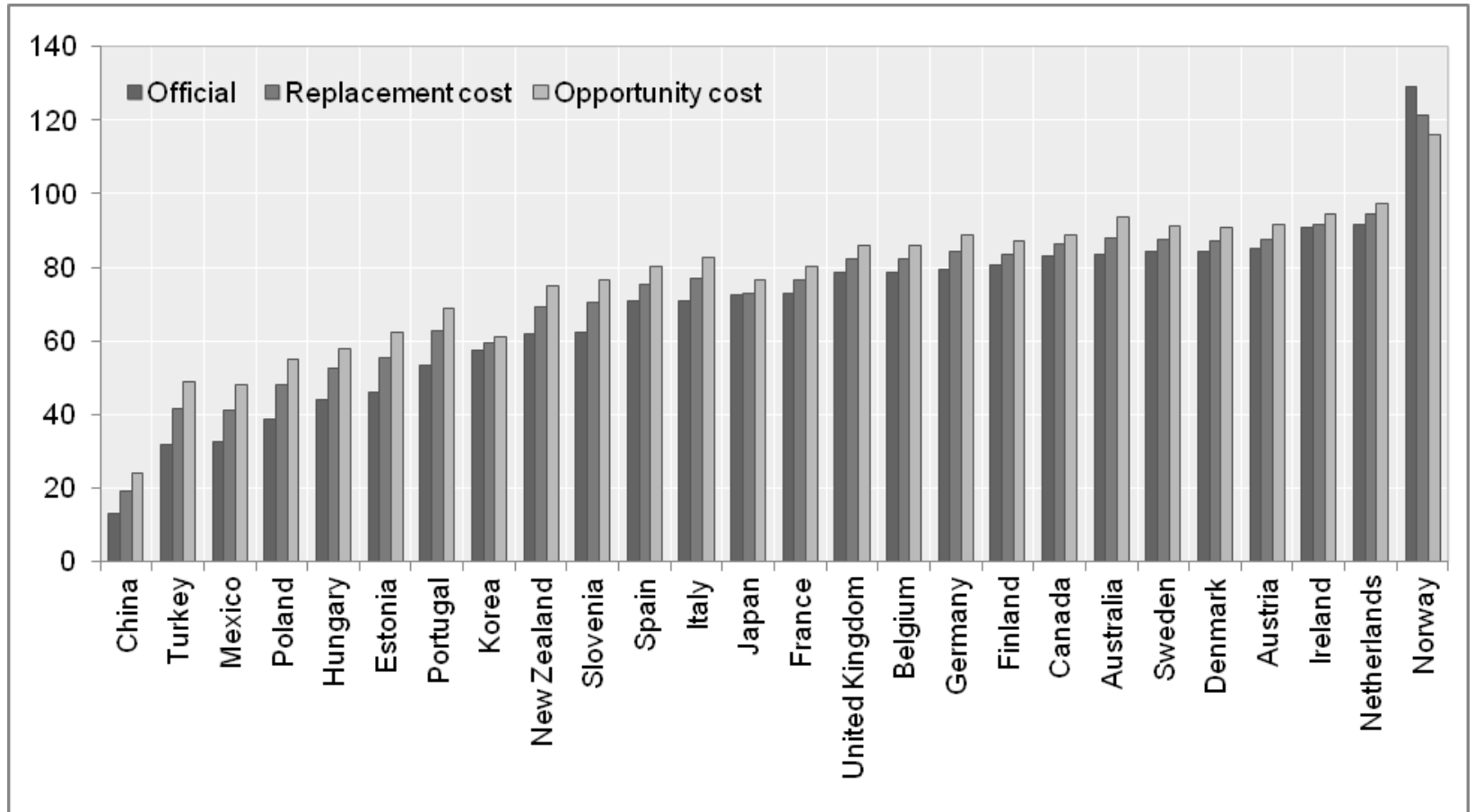


48. Figure 7 below shows estimates of household production of non-market services (valued with the replacement cost approach). It shows that in all countries the contribution of household non-market production as a share of actual individual consumption (on a PPP basis) is higher than in the United States; which partly explains why the addition of household production of non-market services into GDP comparisons improves the position of nearly all countries relative to the United States.

Figure 7: Household consumption of non-market services, labour costs: \% of AIC, 2008 (Replacement cost approach)

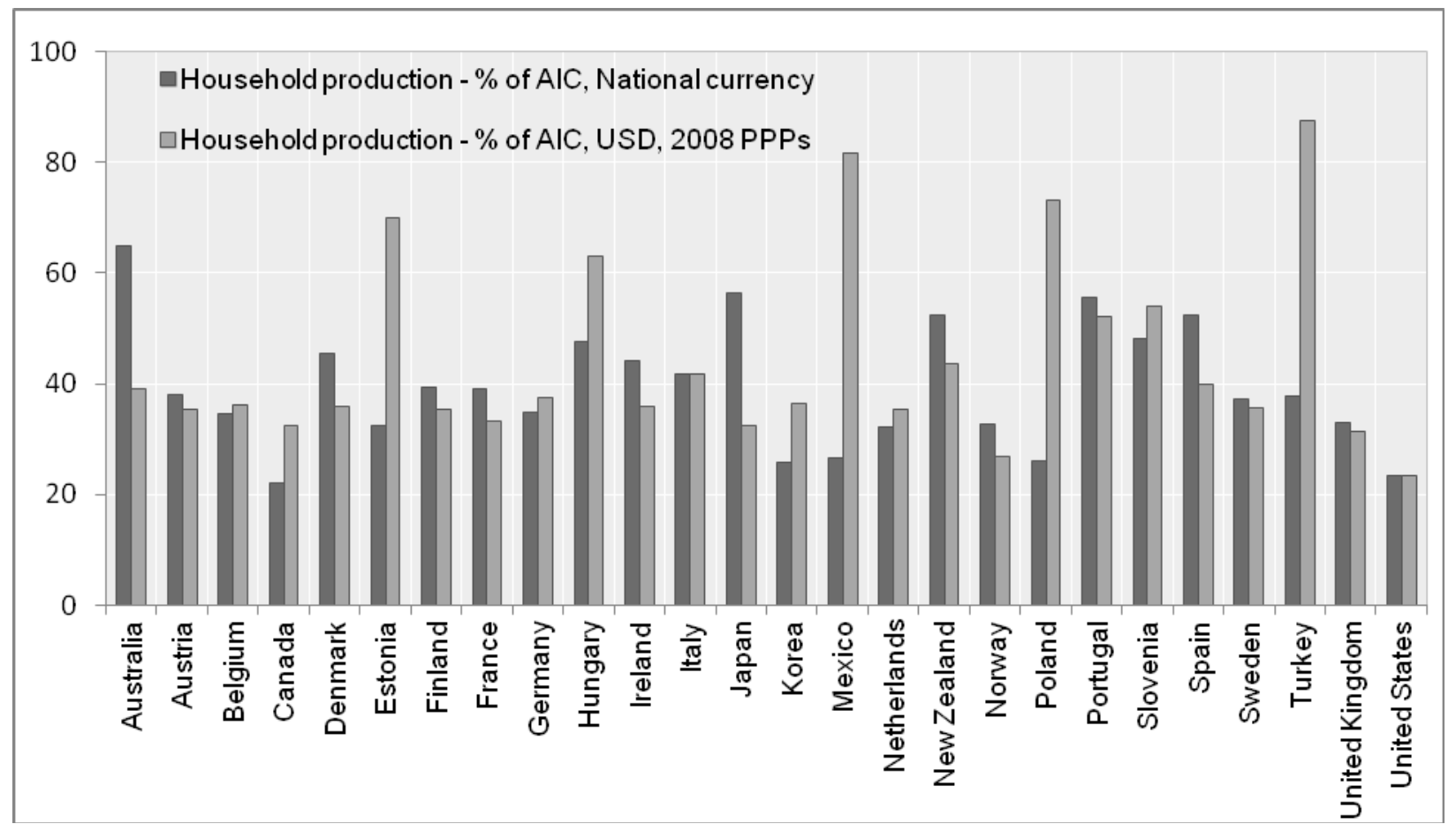

49. In the majority of countries the contribution as a share of AIC is about the same whether measured on a national currency or PPP basis, but in those countries with significantly less income or consumption per capita than the United States, measures based on PPPs are significantly higher than those based on national currencies. For example, in Mexico and Turkey, household production of non-market services is $27 \%$ and $38 \%$ of total AIC respectively, when measured on a national currency basis but $82 \%$ and $88 \%$ when measured on a PPP basis. This to some extent reflects the fact that lower income economies tend to have lower labour costs relative to the price of general goods and services, and relative to the United States, and so the contribution of these labour components makes a significant difference when measured in (PPP) volume terms.

50. Figure 8 below, which shows the ratio of PPPs for AIC relative to the PPPs for household production of non-market services labour costs (for both replacement and opportunity cost approaches) illustrates this. Looking at replacement costs first, it shows relatively high ratios for Turkey, Estonia, Mexico and Poland and indeed relatively low ratios for Japan and Australia. For the majority of countries the ratios are close to 1 . For countries at the extreme ends of the scale, this may of course indicate some degree of unreliability vis-a-vis the prices chosen, which reinforces the message about the care needed in making estimates and indeed reinforces the case for PPP based comparisons. For the opportunity cost approach, the chart suggests that even greater care is needed. 
Figure 8: Ratio of AIC PPPs to household production of non-market services PPPs

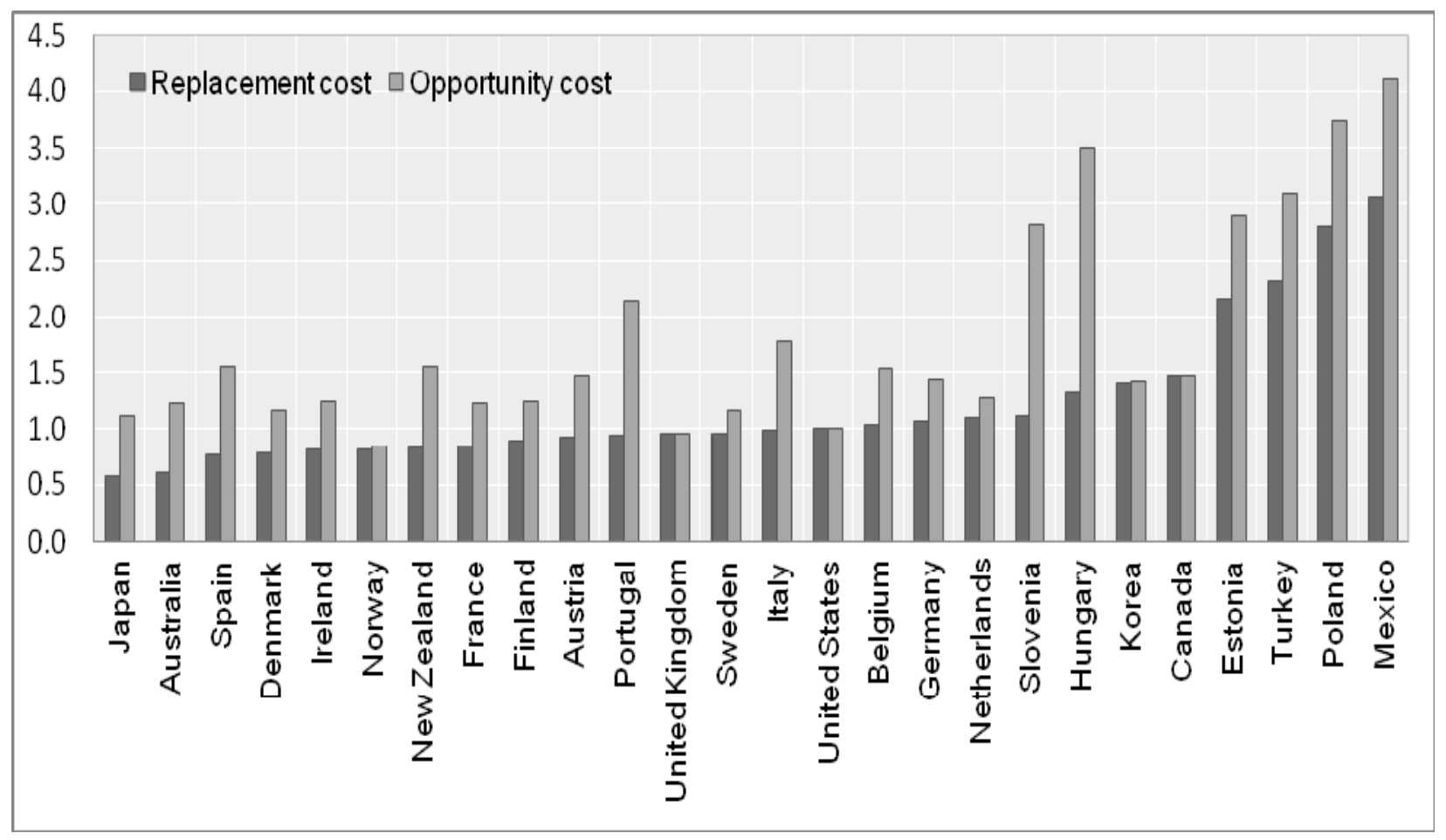

51. But recognising households as producers of household services is only one part of the story. A relatively low share of household production of non-market services in one country relative to another may occur because greater use of capital is made in producing these services in that country relative to the other. Including the contribution of these capital services implies that consumer durables used in the production of these services are recorded as capital. In the same way therefore that estimates of owneroccupied dwellings can be, and often are, estimated using the user-cost approach, so too can estimates of the value of capital services provided by consumer durables.

52. Figure 9 below shows the value of these capital services as a per cent of household production of non-market services (valued using replacement costs). The share varies considerably across countries, ranging from a little under $10 \%$ in Japan to about $30 \%$ in Canada.

53. Figure 10 shows the relative positions of countries including both the contribution from household production of non-market services and the value of capital services provided by consumer durables used in production on a PPP basis across countries. It shows that the value of capital services makes little difference to the overall picture when compared in PPPs relative to the United States (this partly reflects the fact that the lower the expenditure on capital the less official AIC is reduced and classified as capital - if for example all durables were assumed to appreciate in one year the results of including or excluding capital services would be identical). But it is interesting to note that their inclusion results in a marginal improvement in the overall position of the United States relative to all other countries compared to the estimates that include only the contribution of labour costs. 
Figure 9: Capital services from consumer durables as a per cent of household production of non-market services (replacement cost approach) plus capital services, 2008

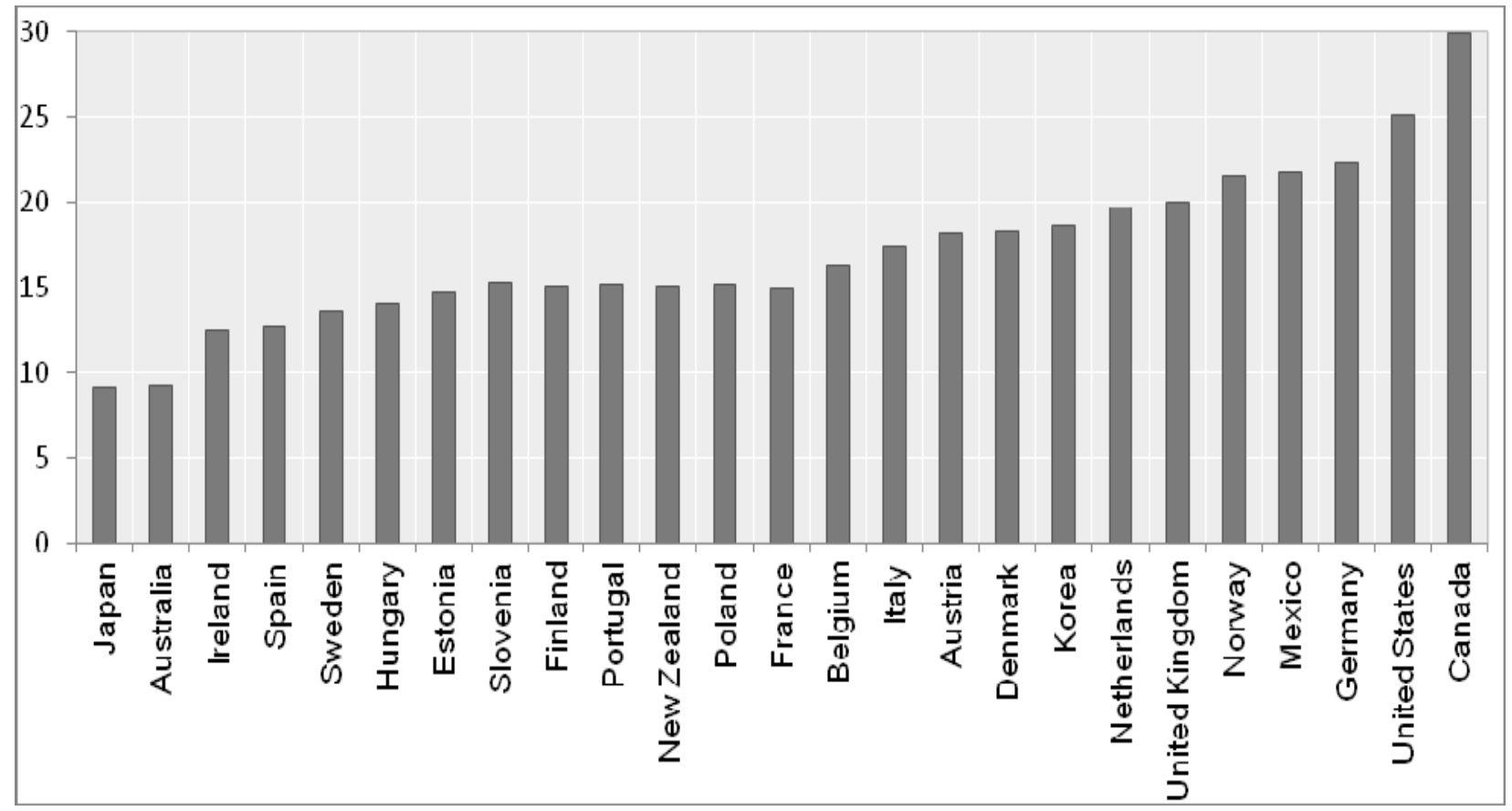

Figure 10: Total household consumption (plus capital services from consumer durables) per capita: 2008 PPPs, US $=100$

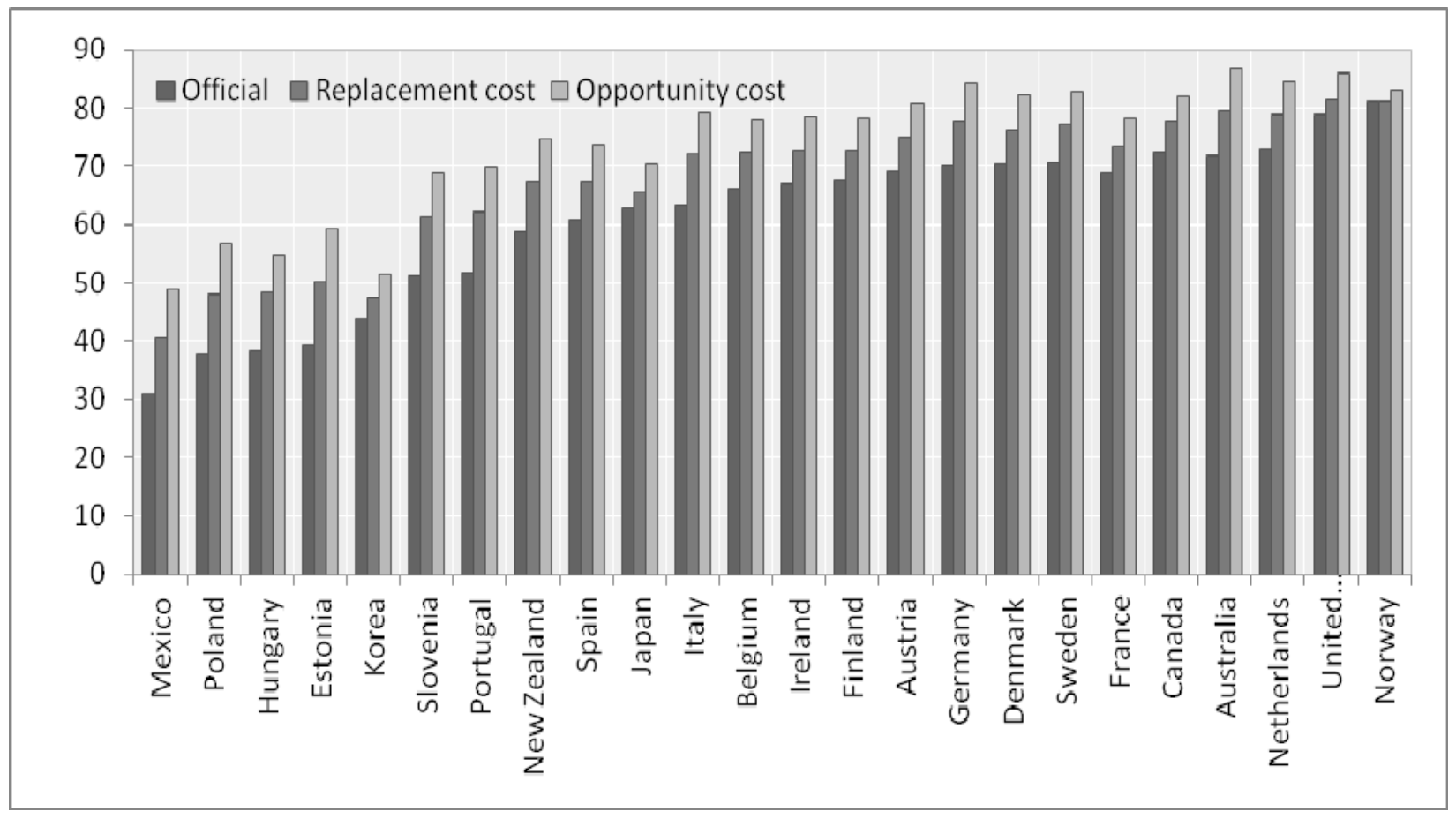




\section{Volume movements over time}

54. This section presents some tentative findings on the change in household production of nonmarket services across five countries with relatively long time-series of Time-Use Surveys: Canada, Netherlands, Norway, the United Kingdom and the United States.

55. The results are described as tentative as the approach used is necessarily crude and because the consistency of time-use surveys over the periods covered is debatable: the data used here is sourced from Multinational Time Use Study (MTUS) ${ }^{9}$, for all years except 2008. The analysis below presents results in volume-terms, in 2008 prices. It presents results for the replacement cost approach and opportunity cost approach, using the prices described in Section 3 above and creates estimates of GDP in 2008 prices by linking estimates of volume GDP in 2000 prices in the OECD National Accounts database.

56. The important caveat in this context therefore relates to the treatment of quality change in the provision of household non-market services. Implicitly, through necessity rather than design, no quality change is assumed in the actual services produced nor is it assumed that there is any productivity change in the time-spent producing them. Both of these assumptions are unlikely to hold and so care is needed in interpreting the results that follow and where further work is needed.

57. Table 4 below shows the starting point of this analysis:

Table 4: Average hours spent per-capita per day on unpaid work

\begin{tabular}{|c|c|c|c|c|c|c|c|c|}
\hline \multirow{2}{*}{$\begin{array}{l}\text { Year } \\
\text { Canada }\end{array}$} & & 1971 & 1981 & 1986 & 1992 & 1998 & & 2008 \\
\hline & & 3.49 & 3.56 & 3.55 & 3.41 & 3.43 & & 3.29 \\
\hline \multirow{2}{*}{$\begin{array}{l}\text { Year } \\
\text { Netherlands }\end{array}$} & & 1975 & 1980 & 1985 & 1990 & 1995 & 2000 & 2008 \\
\hline & & 4.52 & 3.64 & 3.57 & 3.41 & 3.41 & 3.42 & 3.65 \\
\hline \multirow{2}{*}{$\begin{array}{l}\text { Year } \\
\text { Norway }\end{array}$} & & & 1981 & & 1990 & & 2000 & 2008 \\
\hline & & & 3.29 & & 3.49 & & 3.38 & 3.14 \\
\hline \multirow{2}{*}{$\begin{array}{l}\text { Year } \\
\text { UK }\end{array}$} & & & & 1983 & 1987 & 1995 & 2000 & 2008 \\
\hline & & & & 3.56 & 3.50 & 3.07 & 3.69 & 3.52 \\
\hline \multirow{2}{*}{$\begin{array}{l}\text { Year } \\
\text { USA }\end{array}$} & 1965 & 1975 & & 1985 & & 1998 & 2003 & 2008 \\
\hline & 3.81 & 3.60 & & 3.58 & & 3.91 & 3.67 & 3.44 \\
\hline
\end{tabular}

Source: OECD estimates based on national time-use surveys and the multinational time use study (2011)

58. One can note a general trend towards fewer hours spent on un-paid activities if one compares the 1960s and 1970s with the 2000s but no significant change between the 1980s and 2000s. It also reveals oddities, for example the unusually low figure for the United Kingdom in 1995, reinforcing the earlier message for care in interpretation.

9 The time-series for all years apart from 2008 are from the MTUS, which is an international harmonised set of time use surveys composed of identically recoded variables. The MTUS co-ordinating committee www.timeuse.org/mtus/coordinators) regularly updates this dataset (current version: release 2 of the socalled World5.5 version, with nearly 40 selected surveys). The categorisation of activities in MTUS differs slightly from the OECD. The following categories have been defined as unpaid work in this study: cooking/washing up, housework, non-routine domestic work, shopping, childcare, domestic-related travel and education/study activities. The population coverage differs across countries, and across years: Canada 15+ (1971: 18-64); Netherlands 12+ (2000: 11+); Norway 1971-1972: 16-74, 1980-81: 16-74, 1990-91: 16-79, 2000-01: 9+ ; 2003: 15+; United Kingdom: 1961: 15+; 1974-75: 5+; 1983-84: 14+; 1987: 16+; 1995: 16+; 2000: 8+; United States: 1965: 18-64; 1975-76 18+; 1985: 12+; 1992-1994: 0+; 1998-2001: $18+$. 
59. Nevertheless as shown in Table 5 below, assuming no significant changes in the quality of productivity in producing these services, the evidence suggests that as a share GDP, household non-market services have fallen markedly over the last four decades, whatever approach is used to value the services.

Table 5: Household production of non-market services as a per cent of GDP, 2008 prices (replacement and opportunity cost approach, with no adjustment for quality/productivity)

\begin{tabular}{|l|l|rrrrrrr|}
\hline \multirow{3}{*}{ Canada } & Year & 1971 & 1981 & 1986 & 1992 & 1998 & \\
& Replacement & 27 & 23 & 22 & 20 & 18 & 2008 \\
\hline \multirow{3}{*}{ Netherlands } & Opportunity & 71 & 61 & 57 & 54 & 48 & 15 \\
& Year & 1975 & 1980 & 1985 & 1990 & 1995 & 2000 & 2008 \\
& Replacement & 42 & 31 & 31 & 26 & 24 & 20 & 19 \\
& Opportunity & 96 & 72 & 71 & 60 & 55 & 47 & 45 \\
\hline \multirow{3}{*}{ Norway } & Year & & 1981 & & 1990 & & 2000 & 2008 \\
& Replacement & & 32 & & 29 & & 20 & 17 \\
& Opportunity & & 83 & & 75 & & 53 & 45 \\
\hline \multirow{3}{*}{ UK } & Year & & & 1983 & 1987 & 1995 & 2000 & 2008 \\
\hline \multirow{3}{*}{ USA } & Replacement & & & 44 & 38 & 29 & 30 & 26 \\
& Opportunity & & & 118 & 102 & 77 & 80 & 68 \\
\hline & Year & 1975 & & 1985 & & 1998 & 2003 & 2008 \\
\hline & Replacement & 34 & & 28 & & 24 & 20 & 18 \\
& Opportunity & 92 & & 75 & & 63 & 54 & 48 \\
\hline
\end{tabular}

60. Not surprisingly, this also translates into differences in growth rates. Table 6 below compares average annual growth rates of official GDP with those that would be obtained if household production of non-market services were included. The table reveals not-insignificant differences in growth rates compared to official GDP growth rates, and indeed, unlike Landefeld et al., it also reveals not-insignificant differences between the rates calculated for the replacement cost and opportunity cost approach, reinforcing the tentative nature of the results shown in this section and the need for further work, particularly in measures of opportunity cost, which assume the same real average salary in all periods. Of particular note is the marked difference in growth rates for the Netherlands between 1975 and 1980, which reflects the significant fall recorded in Time-Use surveys in the average hour spent on un-paid work over this period. 
STD/DOC(2011)7

Table 6: Average annual growth in GDP including household production of non-market services 2008 prices, $\%$.

\begin{tabular}{|c|c|c|c|c|c|c|c|c|}
\hline \multirow{4}{*}{ Canada } & \multirow{4}{*}{$\begin{array}{l}\text { Period } \\
\text { Official } \\
\text { Replacement } \\
\text { Opportunity }\end{array}$} & $71-81$ & $81-86$ & $86-92$ & $92-98$ & & $98-2008$ & $71-2008$ \\
\hline & & 4.0 & 2.5 & 1.8 & 3.3 & & 2.9 & 2.7 \\
\hline & & 3.7 & 2.3 & 1.6 & 3.0 & & 2.6 & 2.4 \\
\hline & & 3.4 & 2.1 & 1.4 & 2.6 & & 2.3 & 2.1 \\
\hline \multirow{4}{*}{ Netherlands } & \multirow{4}{*}{$\begin{array}{l}\text { Period } \\
\text { Official } \\
\text { Replacement } \\
\text { Opportunity }\end{array}$} & $75-80$ & $80-85$ & $85-90$ & $90-95$ & $95-2000$ & $2000-20008$ & $75-2008$ \\
\hline & & 2.9 & 1.1 & 3.3 & 2.3 & 4.0 & 2.0 & 2.5 \\
\hline & & 1.3 & 1.0 & 2.6 & 2.0 & 3.4 & 1.9 & 2.1 \\
\hline & & 0.3 & 1.0 & 2.0 & 1.7 & 2.9 & 1.8 & 1.9 \\
\hline \multirow{4}{*}{ Norway } & \multirow{4}{*}{$\begin{array}{l}\text { Period } \\
\text { Official } \\
\text { Replacement } \\
\text { Opportunity }\end{array}$} & & & $81-90$ & & $90-2000$ & $2000-20008$ & $81-2008$ \\
\hline & & & & 2.6 & & 3.7 & 2.1 & 2.9 \\
\hline & & & & 2.3 & & 3.0 & 1.8 & 2.4 \\
\hline & & & & 2.1 & & 2.3 & 1.4 & 2.0 \\
\hline \multirow{4}{*}{ UK } & \multirow{4}{*}{$\begin{array}{l}\text { Period } \\
\text { Official } \\
\text { Replacement } \\
\text { Opportunity } \\
\end{array}$} & & & $83-87$ & $87-95$ & $95-2000$ & $2000-2008$ & $83-2008$ \\
\hline & & & & 3.7 & 2.0 & 3.4 & 2.2 & 2.6 \\
\hline & & & & 2.6 & 1.1 & 3.6 & 1.8 & 2.1 \\
\hline & & & & 1.8 & 0.4 & 3.7 & 1.3 & 1.6 \\
\hline \multirow{4}{*}{ USA } & \multirow{4}{*}{$\begin{array}{l}\text { Period } \\
\text { Official } \\
\text { Replacement } \\
\text { Opportunity } \\
\end{array}$} & & $75-85$ & & $85-2003$ & $1998-2003$ & $2003-2008$ & $75-2008$ \\
\hline & & & 3.5 & & 3.2 & 2.9 & 2.2 & 3.1 \\
\hline & & & 3.0 & & 2.9 & 2.3 & 1.9 & 2.7 \\
\hline & & & 2.5 & & 2.6 & 1.8 & 1.4 & 2.3 \\
\hline
\end{tabular}

\section{Conclusions and future plans}

61. The work presented here is to some extent still in its early stages. But illustrates that, even if there is considerable uncertainty about the value of household production of non-market services in a purely national context, meaningful cross country comparisons based on Purchasing Power Parities are obtainable.

62. Certainly the results demonstrate the importance of such comparisons and indeed the importance of including estimates of household non-market production of services in making comparisons of material well-being between countries at the lower and higher end of the income scales. For example for China, calculations on a replacement cost basis improve the per capita position of China relative to the United States by $50 \%$.

63. Whilst the study has demonstrated that meaningful volume comparisons over space are obtainable using readily available statistics, the same cannot (at least yet) be said for volume comparisons over time. The tentative results presented above point to the need for more elaborate data and also the need to recognise and measure differences in the quality of services produced and indeed the productivity in producing them over time. The fact that the quality of these services may change significantly over time may also have implications for the assumption that the quality of services produced in different countries is the same; which is implicit in the calculation and explicit in the derivation of PPPs. Further work on quality is thus merited for both volume and spatial comparisons. These issues will form part of the work programme going forward, as will expanding the country coverage. But a key part of the work programme will be to resolve a number of other issues highlighted above: for example refining the estimates of capital services in order to remove double counting and creating estimates that value leisure. 
Table 7. Household production estimates using the replacement cost approach, 2008

\begin{tabular}{|c|c|c|c|c|c|c|c|c|c|c|c|c|c|c|c|}
\hline & \multirow{2}{*}{$\begin{array}{c}\text { Time } \\
\text { spent on } \\
\text { Unpaid } \\
\text { house } \\
\text { work } \\
\begin{array}{c}\text { Hours per } \\
\text { day per } \\
\text { person }\end{array}\end{array}$} & \multirow{2}{*}{$\begin{array}{c}\text { Population } \\
\text { above } 15 \\
\text { years of } \\
\text { age } \\
\\
\\
1000 \\
\text { persons, } \\
\text { total }\end{array}$} & \multirow{2}{*}{$\begin{array}{c}\begin{array}{c}\text { Value of } \\
\text { unpaid } \\
\text { housework }\end{array} \\
\begin{array}{c}\text { Millions of } \\
\text { national } \\
\text { currency }\end{array}\end{array}$} & \multirow{2}{*}{$\begin{array}{c}\text { Net stock of } \\
\text { consumer } \\
\text { durables } \\
\\
\text { Millions of } \\
\text { chained } 2000 \\
\text { national currency }\end{array}$} & \multirow{2}{*}{$\begin{array}{c}\begin{array}{c}\text { Value of } \\
\text { capital } \\
\text { services } \\
\text { after tax }\end{array} \\
\begin{array}{c}\text { Millions of } \\
\text { national } \\
\text { currency }\end{array}\end{array}$} & \multicolumn{2}{|c|}{$\begin{array}{l}\text { Value of own-account } \\
\text { household production } \\
\text { (HP) }\end{array}$} & \multirow{2}{*}{$\begin{array}{c}\text { AIC } \\
\text { converted } \\
\text { with PPPS } \\
\text { for AIC } \\
\\
\text { USD } \\
\text { per } \\
\text { capita }\end{array}$} & \multirow{2}{*}{$\begin{array}{c}\text { Full } \\
\text { consumption } \\
\text { (AIC+HP), } \\
\text { converted } \\
\text { with adjusted } \\
\text { PPPs } \\
\\
\\
\\
\text { USD } \\
\text { per } \\
\text { capita }\end{array}$} & \multirow{2}{*}{$\begin{array}{c}\text { GDP } \\
\\
\\
\text { USD } \\
\text { per } \\
\text { capita }\end{array}$} & \multirow{2}{*}{$\begin{array}{c}\text { Extended GDP } \\
\text { (GDP+HP), } \\
\text { converted with } \\
\text { adjusted PPPs } \\
\\
\\
\text { USD } \\
\text { per } \\
\text { capita }\end{array}$} & \multirow{2}{*}{$\begin{array}{c}\text { AIC } \\
\text { converted } \\
\text { with PPPS } \\
\text { for AIC } \\
\\
\\
\text { US } \\
=100\end{array}$} & \multirow{2}{*}{$\begin{array}{l}\text { Full } \\
\text { consumption } \\
\text { (AIC+HP), } \\
\text { converted } \\
\text { with adjusted } \\
\text { PPPs } \\
\\
\\
\text { US } \\
=100\end{array}$} & \multirow{2}{*}{$\begin{array}{l}\text { GDP } \\
\\
\text { US } \\
=100\end{array}$} & \multirow{2}{*}{$\begin{array}{c}\text { Extended GDP } \\
\text { (GDP+HP), } \\
\text { converted with } \\
\text { adjusted PPPs } \\
\\
\\
\text { US } \\
=100\end{array}$} \\
\hline & & & & & & $\begin{array}{c}\text { Millions of } \\
\text { national } \\
\text { currency }\end{array}$ & $\begin{array}{l}\% \text { of } \\
\text { GDP }\end{array}$ & & & & & & & & \\
\hline Australia & 4.05 & 17483 & 532333 & 305888 & 54715 & 587048 & $47 \%$ & 25,976 & 35,601 & 39,148 & 48,974 & 72 & 79 & 83 & 88 \\
\hline Austria & 3.38 & 7067 & 68128 & 68739 & 15232 & 83359 & $29 \%$ & 24,994 & 33,537 & 39,849 & 48,361 & 69 & 75 & 85 & 87 \\
\hline Belgium & 3.33 & 8937 & 79302 & 56279 & 15410 & 94713 & $27 \%$ & 23,857 & 32,397 & 36,879 & 45,361 & 66 & 72 & 79 & 82 \\
\hline Canada & 3.29 & 27718 & 238817 & 472653 & 102054 & 340870 & $21 \%$ & 26,099 & 34,824 & 38,883 & 47,461 & 72 & 78 & 83 & 85 \\
\hline Denmark & 3.61 & 4483 & 533829 & 504766 & 120165 & 653994 & $38 \%$ & 25,426 & 34,206 & 39,494 & 48,213 & 70 & 76 & 84 & 87 \\
\hline Estonia & 3.87 & 1110 & 54211 & 49727 & 9340 & 63551 & $25 \%$ & 14,171 & 22,496 & 21,640 & 29,889 & 39 & 50 & 46 & 54 \\
\hline Finland & 3.35 & 4421 & 48208 & 44955 & 8580 & 56788 & $31 \%$ & 24,387 & 32,543 & 37,795 & 45,892 & 67 & 73 & 81 & 83 \\
\hline France & 3.28 & 52406 & 549396 & 488362 & 96109 & 645505 & $33 \%$ & 24,912 & 32,911 & 34,233 & 42,356 & 69 & 73 & 73 & 76 \\
\hline Germany & 3.54 & 71204 & 584718 & 744202 & 168311 & 753029 & $30 \%$ & 25,378 & 34,885 & 37,171 & 46,680 & 70 & 78 & 79 & 84 \\
\hline Hungary & 3.34 & 8537 & 8405457 & 6208014 & 1371325 & 9776782 & $37 \%$ & 13,927 & 21,639 & 20,700 & 28,414 & 39 & 48 & 44 & 51 \\
\hline Ireland & 3.54 & 3526 & 49501 & 33988 & 7043 & 56544 & $31 \%$ & 24,233 & 32,628 & 42,644 & 50,664 & 67 & 73 & 91 & 91 \\
\hline Italy & 3.59 & 51382 & 466069 & 402805 & 98135 & 564203 & $36 \%$ & 22,867 & 32,307 & 33,269 & 42,713 & 63 & 72 & 71 & 77 \\
\hline Japan & 2.73 & 110358 & 193979541 & 130488362 & 19679898 & 213659439 & $42 \%$ & 22,666 & 29,418 & 33,902 & 40,710 & 63 & 66 & 72 & 73 \\
\hline Korea & 2.26 & 40149 & 162559680 & 185346173 & 37275187 & 199834867 & $19 \%$ & 15,845 & 21,299 & 26,877 & 32,300 & 44 & 47 & 57 & 58 \\
\hline Mexico & 4.21 & 75282 & 2259048 & 2263501 & 628361 & 2887409 & $24 \%$ & 11,258 & 18,265 & 15,291 & 22,058 & 31 & 41 & 33 & 40 \\
\hline Netherlands & 3.65 & 13512 & 115997 & 123686 & 28542 & 144539 & $24 \%$ & 26,338 & 35,324 & 42,887 & 51,894 & 73 & 79 & 91 & 93 \\
\hline New Zealand & 3.78 & 3390 & 68213 & 54176 & 12187 & 80400 & $43 \%$ & 21,267 & 30,216 & 29,077 & 38,240 & 59 & 67 & 62 & 69 \\
\hline Norway & 3.14 & 3859 & 430376 & 531415 & 118672 & 549048 & $22 \%$ & 29,272 & 36,441 & 60,622 & 66,796 & 81 & 81 & 129 & 120 \\
\hline Poland & 3.83 & 32253 & 240406 & 191734 & 43085 & 283490 & $22 \%$ & 13,679 & 21,509 & 18,062 & 25,653 & 38 & 48 & 39 & 46 \\
\hline Portugal & 3.71 & 8996 & 74815 & 50684 & 13402 & 88218 & $51 \%$ & 18,664 & 27,913 & 24,962 & 34,375 & 52 & 62 & 53 & 62 \\
\hline Slovenia & 3.84 & 1695 & 11445 & 8095 & 2075 & 13519 & $36 \%$ & 18,452 & 27,501 & 29,241 & 38,298 & 51 & 61 & 62 & 69 \\
\hline Spain & 3.30 & 38898 & 390689 & 227257 & 56939 & 447628 & $41 \%$ & 21,923 & 30,205 & 33,173 & 41,501 & 61 & 67 & 71 & 75 \\
\hline Sweden & 3.55 & 7678 & 787176 & 674812 & 124042 & 911219 & $28 \%$ & 25,580 & 34,597 & 39,475 & 48,456 & 71 & 77 & 84 & 87 \\
\hline United Kingdom & 3.52 & 50488 & 368906 & 486736 & 92433 & 461338 & $32 \%$ & 28,487 & 36,560 & 36,817 & 45,012 & 79 & 81 & 79 & 81 \\
\hline United States & 3.44 & 243169 & 2590250 & 4433386 & 870534 & 3460784 & $24 \%$ & 36,151 & 44,868 & 46,901 & 55,618 & 100 & 100 & 100 & 100 \\
\hline
\end{tabular}

Notes: Data of final consumption expenditures of households on durable goods are unavailable for China and Turkey. 
Table 8. Household production estimates using the opportunity cost approach, 2008

$\operatorname{STD} / \mathrm{DOC}(2011) 7$

\begin{tabular}{|c|c|c|c|c|c|c|c|c|c|c|c|c|c|c|c|}
\hline & $\begin{array}{c}\text { Time } \\
\text { spent on } \\
\text { Unpaid } \\
\text { house } \\
\text { work }\end{array}$ & $\begin{array}{l}\text { Population } \\
\text { above } 15 \\
\text { years of } \\
\text { age }\end{array}$ & $\begin{array}{c}\text { Value of } \\
\text { unpaid } \\
\text { housework }\end{array}$ & $\begin{array}{l}\text { Net stock of } \\
\text { consumer } \\
\text { durables }\end{array}$ & $\begin{array}{l}\text { Value of } \\
\text { capital } \\
\text { services } \\
\text { after tax }\end{array}$ & \multicolumn{2}{|c|}{$\begin{array}{l}\text { Value of own-account } \\
\text { household production } \\
\text { (HP) }\end{array}$} & $\begin{array}{c}\text { AIC } \\
\text { converted } \\
\text { with PPPs } \\
\text { for AIC }\end{array}$ & $\begin{array}{c}\text { Full } \\
\text { consumption } \\
\text { (AIC+HP), } \\
\text { converted } \\
\text { with adjusted } \\
\text { PPPs }\end{array}$ & GDP & $\begin{array}{l}\text { Extended GDP } \\
\text { (GDP+HP), } \\
\text { converted with } \\
\text { adjusted PPPs }\end{array}$ & $\begin{array}{c}\text { AIC } \\
\text { converted } \\
\text { with PPPs } \\
\text { for AIC }\end{array}$ & $\begin{array}{c}\text { Full } \\
\text { consumption } \\
\text { (AIC+HP), } \\
\text { converted } \\
\text { with adjusted } \\
\text { PPPs }\end{array}$ & GDP & $\begin{array}{c}\text { Extended GDP } \\
(\mathrm{GDP}+\mathrm{HP}), \\
\text { converted with } \\
\text { adjusted PPPs }\end{array}$ \\
\hline & $\begin{array}{l}\text { Hours per } \\
\text { day per } \\
\text { person }\end{array}$ & $\begin{array}{l}1000 \\
\text { persons, } \\
\text { total }\end{array}$ & $\begin{array}{l}\text { Millions of } \\
\text { national } \\
\text { currency }\end{array}$ & $\begin{array}{c}\text { Millions of } \\
\text { chained } 2000 \\
\text { national currency }\end{array}$ & $\begin{array}{l}\text { Millions of } \\
\text { national } \\
\text { currency }\end{array}$ & $\begin{array}{l}\text { Millions of } \\
\text { national } \\
\text { currency }\end{array}$ & $\begin{array}{l}\% \text { of } \\
\text { GDP }\end{array}$ & $\begin{array}{l}\text { USD } \\
\text { per } \\
\text { capita }\end{array}$ & $\begin{array}{l}\text { USD } \\
\text { per } \\
\text { capita }\end{array}$ & $\begin{array}{l}\text { USD } \\
\text { per } \\
\text { capita }\end{array}$ & $\begin{array}{l}\text { USD } \\
\text { per } \\
\text { capita }\end{array}$ & $\begin{array}{l}\text { US } \\
=100\end{array}$ & $\begin{array}{l}\text { US } \\
=100\end{array}$ & $\begin{array}{l}\text { US } \\
=100\end{array}$ & $\begin{array}{c}\text { US } \\
=100\end{array}$ \\
\hline Australia & 4.05 & 17483 & 698303 & 305888 & 54715 & 753018 & $60 \%$ & 25,976 & 51,291 & 39,148 & 64,676 & 72 & 87 & 83 & 93 \\
\hline Austria & 3.38 & 7067 & 115441 & 68739 & 15232 & 130673 & $46 \%$ & 24,994 & 47,670 & 39,849 & 62,902 & 69 & 81 & 85 & 90 \\
\hline Belgium & 3.33 & 8937 & 144912 & 56279 & 15410 & 160323 & $46 \%$ & 23,857 & 46,064 & 36,879 & 59,239 & 66 & 78 & 79 & 85 \\
\hline Canada & 3.29 & 27718 & 636099 & 472653 & 102054 & 738153 & $46 \%$ & 26,099 & 48,435 & 38,883 & 61,283 & 72 & 82 & 83 & 88 \\
\hline Denmark & 3.61 & 4483 & 962602 & 504766 & 120165 & 1082767 & $62 \%$ & 25,426 & 48,634 & 39,494 & 62,932 & 70 & 82 & 84 & 90 \\
\hline Estonia & 3.87 & 1110 & 108423 & 49727 & 9340 & 117763 & $47 \%$ & 14,171 & 35,038 & 21,640 & 42,176 & 39 & 59 & 46 & 60 \\
\hline Finland & 3.35 & 4421 & 92730 & 44955 & 8580 & 101311 & $55 \%$ & 24,387 & 46,185 & 37,795 & 59,814 & 67 & 78 & 81 & 86 \\
\hline France & 3.28 & 52406 & 1022856 & 488362 & 96109 & 1118964 & $57 \%$ & 24,912 & 46,326 & 34,233 & 55,568 & 69 & 78 & 73 & 80 \\
\hline Germany & 3.54 & 71204 & 1177610 & 744202 & 168311 & 1345921 & $54 \%$ & 25,378 & 49,764 & 37,171 & 61,552 & 70 & 84 & 79 & 88 \\
\hline Hungary & 3.34 & 8537 & 8487291 & 6208014 & 1371325 & 9858616 & $37 \%$ & 13,927 & 32,312 & 20,700 & 38,646 & 39 & 55 & 44 & 55 \\
\hline Ireland & 3.54 & 3526 & 86458 & 33988 & 7043 & 93500 & $52 \%$ & 24,233 & 46,410 & 42,644 & 65,276 & 67 & 79 & 91 & 93 \\
\hline Italy & 3.59 & 51382 & 702785 & 402805 & 98135 & 800920 & $51 \%$ & 22,867 & 46,778 & 33,269 & 56,908 & 63 & 79 & 71 & 81 \\
\hline Japan & 2.73 & 110358 & 266309877 & 130488362 & 19679898 & 285989774 & $57 \%$ & 22,666 & 41,556 & 33,902 & 52,938 & 63 & 70 & 72 & 76 \\
\hline Korea & 2.26 & 40149 & 431270701 & 185346173 & 37275187 & 468545888 & $46 \%$ & 15,845 & 30,293 & 26,877 & 41,691 & 44 & 51 & 57 & 60 \\
\hline Mexico & 4.21 & 75282 & 4518096 & 2263501 & 628361 & 5146457 & $42 \%$ & 11,258 & 28,938 & 15,291 & 31,947 & 31 & 49 & 33 & 46 \\
\hline Netherlands & 3.65 & 13512 & 265669 & 123686 & 28542 & 294211 & $49 \%$ & 26,338 & 49,945 & 42,887 & 67,052 & 73 & 85 & 91 & 96 \\
\hline New Zealand & 3.78 & 3390 & 98196 & 54176 & 12187 & 110383 & $59 \%$ & 21,267 & 44,028 & 29,077 & 51,473 & 59 & 75 & 62 & 74 \\
\hline Norway & 3.14 & 3859 & 1121691 & 531415 & 118672 & 1240363 & $49 \%$ & 29,272 & 49,101 & 60,622 & 80,300 & 81 & 83 & 129 & 115 \\
\hline Poland & 3.83 & 32253 & 480812 & 191734 & 43085 & 523896 & $41 \%$ & 13,679 & 33,620 & 18,062 & 36,862 & 38 & 57 & 39 & 53 \\
\hline Portugal & 3.71 & 8996 & 87626 & 50684 & 13402 & 101028 & $59 \%$ & 18,664 & 41,250 & 24,962 & 46,758 & 52 & 70 & 53 & 67 \\
\hline Slovenia & 3.84 & 1695 & 12255 & 8095 & 2075 & 14330 & $38 \%$ & 18,452 & 40,698 & 29,241 & 51,430 & 51 & 69 & 62 & 74 \\
\hline Spain & 3.30 & 38898 & 512213 & 227257 & 56939 & 569152 & $52 \%$ & 21,923 & 43,614 & 33,173 & 54,887 & 61 & 74 & 71 & 79 \\
\hline Sweden & 3.55 & 7678 & 1725291 & 674812 & 124042 & 1849334 & $58 \%$ & 25,580 & 48,976 & 39,475 & 63,113 & 71 & 83 & 84 & 90 \\
\hline United Kingdom & 3.52 & 50488 & 981179 & 486736 & 92433 & 1073612 & $74 \%$ & 28,487 & 50,754 & 36,817 & 59,235 & 79 & 86 & 79 & 85 \\
\hline United States & 3.44 & 243169 & 6925596 & 4433386 & 870534 & 7796130 & $55 \%$ & 36,151 & 59,091 & 46,901 & 69,840 & 100 & 100 & 100 & 100 \\
\hline
\end{tabular}

Notes: Data of final consumption expenditures of households on durable goods are unavailable for China and Turkey. 
Table 9. Household production estimates, labour costs, using the replacement cost approach, 2008

\begin{tabular}{|c|c|c|c|c|c|c|c|c|c|c|c|c|}
\hline & $\begin{array}{l}\text { Time } \\
\text { spent on } \\
\text { Unpaid } \\
\text { housework }\end{array}$ & $\begin{array}{l}\text { Population } \\
\text { above } 15 \\
\text { years of } \\
\text { age }\end{array}$ & $\begin{array}{l}\text { Value of } \\
\text { account ho } \\
\text { production }\end{array}$ & $\begin{array}{l}\text { Nn- } \\
\text { ehold } \\
\text { (HP) }\end{array}$ & $\begin{array}{c}\text { AIC } \\
\text { converted } \\
\text { with PPPs } \\
\text { for AIC }\end{array}$ & $\begin{array}{c}\text { Full } \\
\text { consumption } \\
\text { (AIC+HP), } \\
\text { converted } \\
\text { with adjusted } \\
\text { PPPs }\end{array}$ & GDP & $\begin{array}{c}\text { Extended } \\
\text { GDP } \\
\text { (GDP+HP), } \\
\text { converted } \\
\text { with adjusted } \\
\text { PPPs }\end{array}$ & $\begin{array}{c}\text { AIC } \\
\text { converted } \\
\text { with PPPs for } \\
\text { AIC }\end{array}$ & $\begin{array}{c}\text { Full } \\
\text { consumption } \\
\text { (AIC+HP), } \\
\text { converted } \\
\text { with adjusted } \\
\text { PPPs }\end{array}$ & GDP & $\begin{array}{c}\text { Extended } \\
\text { GDP } \\
\text { (GDP+HP), } \\
\text { converted } \\
\text { with } \\
\text { adjusted } \\
\text { PPPs }\end{array}$ \\
\hline & $\begin{array}{l}\text { Hours per } \\
\text { day per } \\
\text { person }\end{array}$ & $\begin{array}{c}1000 \\
\text { persons, } \\
\text { total }\end{array}$ & $\begin{array}{l}\text { Millions of } \\
\text { national } \\
\text { currency }\end{array}$ & $\begin{array}{l}\% \text { of } \\
\text { GDP }\end{array}$ & $\begin{array}{l}\text { USD } \\
\text { per } \\
\text { capita }\end{array}$ & $\begin{array}{l}\text { USD } \\
\text { per } \\
\text { capita }\end{array}$ & $\begin{array}{l}\text { USD } \\
\text { per } \\
\text { capita }\end{array}$ & $\begin{array}{l}\text { USD } \\
\text { per } \\
\text { capita }\end{array}$ & $\begin{array}{c}\text { US } \\
=100\end{array}$ & $\begin{array}{c}\text { US } \\
=100\end{array}$ & $\begin{array}{c}\text { US } \\
=100\end{array}$ & $\begin{array}{c}\text { US } \\
=100\end{array}$ \\
\hline Australia & 4.05 & 17483 & 532333 & $42 \%$ & 25,976 & 35,890 & 39,148 & 48,830 & 72 & 80 & 83 & 88 \\
\hline Belgium & 3.33 & 8937 & 79302 & $23 \%$ & 23,857 & 32,433 & 36,879 & 45,456 & 66 & 73 & 79 & 82 \\
\hline Canada & 3.29 & 27718 & 238817 & $15 \%$ & 26,099 & 34,841 & 38,883 & 47,765 & 72 & 78 & 83 & 86 \\
\hline China & 2.73 & 1055358 & 5325110 & $17 \%$ & N.A. & N.A. & 6,190 & 10,647 & N.A. & N.A. & 13 & 19 \\
\hline Denmark & 3.61 & 71204 & 584718 & $24 \%$ & 25,378 & 34,844 & 37,171 & 46,659 & 70 & 78 & 79 & 84 \\
\hline Estonia & 3.87 & 4483 & 533829 & $31 \%$ & 25,426 & 34,346 & 39,494 & 48,225 & 70 & 77 & 84 & 87 \\
\hline Finland & 3.35 & 38898 & 390689 & $36 \%$ & 21,923 & 30,524 & 33,173 & 41,651 & 61 & 68 & 71 & 75 \\
\hline France & 3.28 & 4421 & 48208 & $26 \%$ & 24,387 & 32,896 & 37,795 & 46,220 & 67 & 74 & 81 & 83 \\
\hline Germany & 3.54 & 52406 & 549396 & $28 \%$ & 24,912 & 33,059 & 34,233 & 42,352 & 69 & 74 & 73 & 76 \\
\hline Hungary & 3.34 & 50488 & 368906 & $26 \%$ & 28,487 & 37,362 & 36,817 & 45,678 & 79 & 84 & 79 & 82 \\
\hline Ireland & 3.54 & 8537 & 8405457 & $31 \%$ & 13,927 & 22,322 & 20,700 & 29,084 & 39 & 50 & 44 & 53 \\
\hline Japan & 2.73 & 51382 & 466069 & $30 \%$ & 22,867 & 32,317 & 33,269 & 42,698 & 63 & 72 & 71 & 77 \\
\hline Korea & 2.26 & 110358 & 193979541 & $38 \%$ & 22,666 & 29,473 & 33,902 & 40,448 & 63 & 66 & 72 & 73 \\
\hline Mexico & 4.21 & 40149 & 162559680 & $16 \%$ & 15,845 & 21,698 & 26,877 & 32,908 & 44 & 49 & 57 & 59 \\
\hline Netherlands & 3.65 & 75282 & 2259048 & $19 \%$ & 11,258 & 18,977 & 15,291 & 22,867 & 31 & 43 & 33 & 41 \\
\hline New Zealand & 3.78 & 13512 & 115997 & $19 \%$ & 26,338 & 35,621 & 42,887 & 52,284 & 73 & 80 & 91 & 94 \\
\hline Norway & 3.14 & 3859 & 430376 & $17 \%$ & 29,272 & 36,777 & 60,622 & 67,312 & 81 & 82 & 129 & 122 \\
\hline Poland & 3.83 & 3390 & 68213 & $37 \%$ & 21,267 & 30,469 & 29,077 & 38,259 & 59 & 68 & 62 & 69 \\
\hline Portugal & 3.71 & 32253 & 240406 & $19 \%$ & 13,679 & 22,360 & 18,062 & 26,546 & 38 & 50 & 39 & 48 \\
\hline Slovenia & 3.84 & 8996 & 74815 & $43 \%$ & 18,664 & 28,317 & 24,962 & 34,630 & 52 & 63 & 53 & 63 \\
\hline Spain & 3.30 & 7678 & 787176 & $25 \%$ & 25,580 & 34,638 & 39,475 & 48,499 & 71 & 78 & 84 & 88 \\
\hline Sweden & 3.55 & 52080 & 266566 & $28 \%$ & 10,649 & 18,635 & 14,962 & 22,933 & 29 & 42 & 32 & 41 \\
\hline Turkey & 4.11 & 243169 & 2590250 & $18 \%$ & 36,151 & 44,649 & 46,901 & 55,398 & 100 & 100 & 100 & 100 \\
\hline United Kingdom & 3.52 & 1110 & 54211 & $22 \%$ & 14,171 & 23,052 & 21,640 & 30,639 & 39 & 52 & 46 & 55 \\
\hline United States & 3.44 & 1695 & 11445 & $31 \%$ & 18,452 & 28,221 & 29,241 & 39,049 & 51 & 63 & 62 & 70 \\
\hline
\end{tabular}

Source: OECD household production database (2011) 
Table 10. Household production estimates, labour costs, using the opportunity cost approach, 2008

$\operatorname{STD} / \mathrm{DOC}(2011) 7$

\begin{tabular}{|c|c|c|c|c|c|c|c|c|c|c|c|c|}
\hline & $\begin{array}{c}\text { Time } \\
\text { spent on } \\
\text { Unpaid } \\
\text { housework }\end{array}$ & $\begin{array}{l}\text { Population } \\
\text { above } 15 \\
\text { years of } \\
\text { age }\end{array}$ & $\begin{array}{l}\text { Value of } \\
\text { account ho } \\
\text { production }\end{array}$ & $\begin{array}{l}\text { Nn- } \\
\text { ehold } \\
\text { (HP) }\end{array}$ & $\begin{array}{c}\text { AIC } \\
\text { converted } \\
\text { with PPPs } \\
\text { for AIC }\end{array}$ & $\begin{array}{c}\text { Full } \\
\text { consumption } \\
\text { (AIC+HP), } \\
\text { converted } \\
\text { with adjusted } \\
\text { PPPs }\end{array}$ & GDP & $\begin{array}{c}\text { Extended } \\
\text { GDP } \\
\text { (GDP+HP), } \\
\text { converted } \\
\text { with adjusted } \\
\text { PPPs }\end{array}$ & $\begin{array}{c}\text { AIC } \\
\text { converted } \\
\text { with PPPs for } \\
\text { AIC }\end{array}$ & $\begin{array}{c}\text { Full } \\
\text { consumption } \\
\text { (AIC+HP), } \\
\text { converted } \\
\text { with adjusted } \\
\text { PPPs }\end{array}$ & GDP & $\begin{array}{c}\text { Extended } \\
\text { GDP } \\
\text { (GDP+HP), } \\
\text { converted } \\
\text { with } \\
\text { adjusted } \\
\text { PPPs }\end{array}$ \\
\hline & $\begin{array}{l}\text { Hours per } \\
\text { day per } \\
\text { person }\end{array}$ & $\begin{array}{c}1000 \\
\text { persons, } \\
\text { total }\end{array}$ & $\begin{array}{l}\text { Millions of } \\
\text { national } \\
\text { currency }\end{array}$ & $\begin{array}{l}\% \text { of } \\
\text { GDP }\end{array}$ & $\begin{array}{l}\text { USD } \\
\text { per } \\
\text { capita }\end{array}$ & $\begin{array}{l}\text { USD } \\
\text { per } \\
\text { capita }\end{array}$ & $\begin{array}{l}\text { USD } \\
\text { per } \\
\text { capita }\end{array}$ & $\begin{array}{l}\text { USD } \\
\text { per } \\
\text { capita }\end{array}$ & $\begin{array}{c}\text { US } \\
=100\end{array}$ & $\begin{array}{c}\text { US } \\
=100\end{array}$ & $\begin{array}{c}\text { US } \\
=100\end{array}$ & $\begin{array}{c}\text { US } \\
=100\end{array}$ \\
\hline Australia & 4.05 & 17483 & 698303 & $56 \%$ & 25,976 & 51,727 & 39,148 & 65,292 & 72 & 88 & 83 & 94 \\
\hline Belgium & 3.33 & 8937 & 144912 & $42 \%$ & 23,857 & 46,156 & 36,879 & 59,807 & 66 & 78 & 79 & 86 \\
\hline Canada & 3.29 & 27718 & 636099 & $40 \%$ & 26,099 & 48,469 & 38,883 & 61,785 & 72 & 82 & 83 & 89 \\
\hline China & 2.73 & 1055358 & 14237841 & $45 \%$ & N.A. & N.A. & 6190 & 16844 & N.A. & N.A. & 13 & 24 \\
\hline Denmark & 3.61 & 4483 & 962602 & $55 \%$ & 25,426 & 48,838 & 39,494 & 63,333 & 70 & 83 & 84 & 91 \\
\hline Estonia & 3.87 & 1110 & 108423 & $43 \%$ & 14,171 & 35,803 & 21,640 & 43,501 & 39 & 61 & 46 & 62 \\
\hline Finland & 3.35 & 4421 & 92730 & $50 \%$ & 24,387 & 46,636 & 37,795 & 60,536 & 67 & 79 & 81 & 87 \\
\hline France & 3.28 & 52406 & 1022856 & $52 \%$ & 24,912 & 46,542 & 34,233 & 55,899 & 69 & 79 & 73 & 80 \\
\hline Germany & 3.54 & 71204 & 1177610 & $47 \%$ & 25,378 & 49,755 & 37,171 & 61,897 & 70 & 85 & 79 & 89 \\
\hline Hungary & 3.34 & 8537 & 8487291 & $32 \%$ & 13,927 & 33,314 & 20,700 & 40,224 & 39 & 57 & 44 & 58 \\
\hline Ireland & 3.54 & 3526 & 86458 & $48 \%$ & 24,233 & 46,617 & 42,644 & 65,892 & 67 & 79 & 91 & 95 \\
\hline Japan & 2.73 & 110358 & 266309877 & $53 \%$ & 22,666 & 41,685 & 33,902 & 53,212 & 63 & 71 & 72 & 76 \\
\hline Korea & 2.26 & 40149 & 431270701 & $42 \%$ & 15,845 & 30,756 & 26,877 & 42,482 & 44 & 52 & 57 & 61 \\
\hline Mexico & 4.21 & 75282 & 4518096 & $37 \%$ & 11,258 & 29,928 & 15,291 & 33,355 & 31 & 51 & 33 & 48 \\
\hline Netherlands & 3.65 & 13512 & 265669 & $45 \%$ & 26,338 & 50,311 & 42,887 & 67,762 & 73 & 85 & 91 & 97 \\
\hline New Zealand & 3.78 & 3390 & 98196 & $53 \%$ & 21,267 & 44,403 & 29,077 & 52,085 & 59 & 75 & 62 & 75 \\
\hline Norway & 3.14 & 3859 & 1121691 & $45 \%$ & 29,272 & 49,464 & 60,622 & 80,828 & 81 & 84 & 129 & 116 \\
\hline Poland & 3.83 & 32253 & 480812 & $38 \%$ & 13,679 & 34,796 & 18,062 & 38,402 & 38 & 59 & 39 & 55 \\
\hline Portugal & 3.71 & 8996 & 87626 & $51 \%$ & 18,664 & 41,852 & 24,962 & 47,816 & 52 & 71 & 53 & 69 \\
\hline Slovenia & 3.84 & 1695 & 12255 & $33 \%$ & 18,452 & 41,732 & 29,241 & 53,299 & 51 & 71 & 62 & 77 \\
\hline Spain & 3.30 & 38898 & 512213 & $47 \%$ & 21,923 & 44,082 & 33,173 & 55,767 & 61 & 75 & 71 & 80 \\
\hline Sweden & 3.55 & 7678 & 1725291 & $54 \%$ & 25,580 & 49,059 & 39,475 & 63,411 & 71 & 83 & 84 & 91 \\
\hline Turkey & 4.11 & 52080 & 533132 & $56 \%$ & 10,649 & 29,866 & 14,962 & 33,896 & 29 & 51 & 32 & 49 \\
\hline United Kingdom & 3.52 & 50488 & 981179 & $68 \%$ & 28,487 & 51,627 & 36,817 & 59,845 & 79 & 88 & 79 & 86 \\
\hline United States & 3.44 & 243169 & 6925596 & $48 \%$ & 36,151 & 58,871 & 46,901 & 69,621 & 100 & 100 & 100 & 100 \\
\hline
\end{tabular}




\section{Bibliography}

Abraham, Katherine and Christopher Mackie (eds.) (2005), Beyond the Market: Designing Non-market Accounts for the United States, The National Academy of Sciences.

Chadeau, Ann (1983), Measuring Household Activities: Some International Comparisons, International Association for Research in Income and Wealth, France.

Chadeau, Ann and Caroline Roy (1985), Relating Households' Final Consumption to Household Activities: Substitutability or Complementarity between Market and Non-Market Production, International Association for Research in Income and Wealth, France.

Duran, Maria-Angeles (2007), The Satellite Account for Unpaid Work in the Community of Madrid, La Suma de Todos, Couuminty de Madrid 36.

Eurostat (2003), Proposal for a Methodology of Household Satellite Accounts, Household Production and Consumption, Task Force Report for Eurostat.

Eurostat-OECD (2006), Methodological Manual on Purchasing Power Parities.

Eurostat, IMF, OECD, UN and World Bank (1993), System of National Accounts.

Fraumeni, Barbara (2008), Household Production Accounts for Canada, Mexico, and the United States: Methodological Issues, Results, and Recommendations.

Francis, Perry and Harminder Tiwana (2004), Unpaid Household Production in the United Kingdom, 1995-2000, Economic Trends, No. 602 (January), Office for National Statistics, London, pp. 58-66.

Hamdad, Malika (2003), Valuing Households' Unpaid Work in Canada, 1992 and 1998: Trends and Sources of Change, Statistics Canada Economic Conference, May 2003.

Harvey, Andrew S. and Arun K. Mukhopadhyay (2005), Household Production in Canada:Measuring and Valuing Outputs, in T. V. Hoa (ed.), Advances in Household Economics, Consumer Behaviour and Economic Policy, Ashgate, U.K., pp. 70-84.

Holloway, Sue, Sandra Short and Sarah Tamplin (2002), Household Satellite Account (Experimental) Methodology, UK Office for National Statistics.

Jorgenson, Dale W. and Zvi Griliches (1967), The Explanation of Productivity Change, Review of Economic Studies, 34(3), pp. 249-283.

Landefeld, Steven, Barbara Fraumeni and Cindy M. Vojtech (2008); Accounting for Nonmarket Production: A Prototipe Satellite Account Using the American Time Use Survey.

OECD (2008), Taxing Wages 2007-2008.

OECD (2009), Measuring Capital OECD Manual, $2^{\text {nd }}$ edition.

Pigou, Arthur C. (1932), The Economics of Welfare, 4th edition (originally published in 1920), Macmillan, London. 
Prado, Crinstina and Lourdes Llorens Abando, Satellite Account of Household Production for the Basque Country.

Reid, Margaret (1934), The Economics of Household Production, Wiley, New York.

Ruger, Yvonne and Johanna Varjonen (2008), Value of Household Production in Finland and Germany, Working Paper 112, National Consumer Research Centre, Finland.

Schäfer, Dieter (2004), Unbezhlte Arbeit und Bruttoinlandsprodukt 1992 and 2001: Neuberechnung des Haushasts-Satellitensystems, Wirtschaft und Statistik, 9, pp. 960-78.

Soupourmas, Faye and Duncan Ironmonger, Calculating Australia's Gross Household Product: Measuring the Economic Value of the Household Economy 1970-2000, University of Melbourne, Department of Economics, Working Paper 833.

Szép, Katalin (2003), Összefoglalás Helyett-A Nemzeti Számlákban nem Kimutatott Häztartási Termelési Szamlája és a Jövöbeli Feladatok, in A Háztartási Termelés Érteke a Mai Magyarországon, Hungarian Central Statistical Office, 185-7.

United Nations International Research and Training Institute for the Advancement of Women (UNINSTRAW) (1996), Valuation of Household Production and the Satellite Accounts, INSTRAW, Series B,52.

Varjonen, Johanna and Kristiina Aalto (2006), Household Production and Consumption in Finland 2001: Household Satellite Account, Statistics Finland and National Consumer Research Centre. 